OPEN ACCESS

International Journal of

Environmental Research and

Public Health

ISSN 1660-4601

www.mdpi.com/journal/ijerph

Review

\title{
The Potential of Sequential Extraction in the Characterisation and Management of Wastes from Steel Processing: A Prospective Review
}

\author{
Kiri J. Rodgers, Andrew Hursthouse ${ }^{\dagger, *}$ and Simon Cuthbert ${ }^{\dagger}$ \\ School of Science \& Sport, University of the West of Scotland, Paisley Campus, Paisley PA1 2BE, \\ UK; E-Mails: kiri.rodgers@uws.ac.uk (K.J.R.); Simon.Cuthbert@uws.ac.uk (S.C.) \\ $\dagger$ These authors contributed equally to this work. \\ * Author to whom correspondence should be addressed; E-Mail: andrew.hursthouse@uws.ac.uk; \\ Tel.: +44-0141-838-3213.
}

Academic Editor: Oladele A. Ogunseitan

Received: 1 July 2015 / Accepted: 9 September 2015 / Published: 18 September 2015

\begin{abstract}
As waste management regulations become more stringent, yet demand for resources continues to increase, there is a pressing need for innovative management techniques and more sophisticated supporting analysis techniques. Sequential extraction (SE) analysis, a technique previously applied to soils and sediments, offers the potential to gain a better understanding of the composition of solid wastes. SE attempts to classify potentially toxic elements (PTEs) by their associations with phases or fractions in waste, with the aim of improving resource use and reducing negative environmental impacts. In this review we explain how SE can be applied to steel wastes. These present challenges due to differences in sample characteristics compared with materials to which SE has been traditionally applied, specifically chemical composition, particle size and $\mathrm{pH}$ buffering capacity, which are critical when identifying a suitable SE method. We highlight the importance of delineating iron-rich phases, and find that the commonly applied BCR (The community Bureau of reference) extraction method is problematic due to difficulties with zinc speciation (a critical steel waste constituent), hence a substantially modified SEP is necessary to deal with particular characteristics of steel wastes. Successful development of SE for steel wastes could have wider implications, e.g., for the sustainable management of fly ash and mining wastes.
\end{abstract}


Keywords: sequential extraction; chemical speciation; steel wastes; regulation

\section{Introduction}

In 2013, approximately 1.6 billion tonnes of crude steel were produced worldwide [1,2] with as much as $400 \mathrm{~kg}$ of solid waste created per tonne of steel produced [3]. Steel wastes contain significant quantities of potentially toxic elements (PTEs) that require robust management, including assessment and disposal, to minimise environmental contamination. The European Union (EU) waste management protocols that govern approaches to assessment and disposal in member states [4] are based upon identifying the presence of hazardous substances and their potential impact on the environment and human health. This has resulted in the development of waste classification into inert, non-hazardous and hazardous classes, which are disposed of accordingly. These waste are disposed of accordingly with costs increasing annually throughout the majority of the EU causing financial pressures (not including any additional gate fees or operator charges [5-8]. This approach has been adopted by many European countries [7,9] leading to increased controls and higher costs for disposal, resulting in increased pressure to recycle and re-use materials within the industrial life cycle [10].

A better understanding of the chemical composition of the wastes generated during steel production can enhance their management, in particular for re-use, recycling or more suitable disposal options. This can only be viable if the methodology is robust and accessible for routine industrial application. The semi-continuous nature of steel manufacturing means that wastes, whilst broadly consistent in their primary characteristics, show high variability in concentration of many PTEs of high environmental concern. For metal contaminants, associations with reactive phases and chemical form (speciation) are fundamental controls on their release, transport and environmental impact. Speciation can be derived from direct characterisation techniques such as those using synchrotron x-ray techniques (e.g., XANES and EXAFS) [11] but compositional variability and the complexity of the analytical procedures makes them unattractive for routine analysis.

Fractionation methods have been applied widely to characterise the environmental reactivity of PTEs in fluid and solid phases for many years. For solid phases sequential extraction (SE) is one such technique that can be used to characterise different material fractions, each of which consists of phases with which PTEs are associated. Over the past four decades the majority of SE applications have focused on soil and sediment samples [12], but application to industrial wastes (including those from steel production) has been much less common. Adaption of SE methods to different materials requires that differences in their reactivity (e.g., buffering capacity) be taken into account. Modification of extraction protocols has been shown [13] to be prone to interference from sample specific solubility limiting reactions [14]. Nevertheless, SE leaching protocols developed for a variety of wastes from construction, mining and incineration operations have provided valuable information about their characteristics $[13,15,16]$ that aids in waste management decision support.

In this contribution we explore how such an approach may make SE applicable as a characterisation tool for steel wastes. We review the development of sequential extraction procedures, identify options for future investigation, and highlight problematic components of waste streams. The goal for the 
successful development of improved characterisation methods is to provide a stepping-stone for the development of alternative end-of-life-cycle industrial waste management [17].

\subsection{Need for Improvements to Screening Protocols?}

The steel industry is an important and highly relevant case study due to the continuing growth of steel production (Figure 1), world steel demand grew by $3.6 \%$ and was predicted to grow by $3.1 \%$ in $2014[2,18,19]$ the remainder still represents a very large mass requiring disposal, e.g., the 1.6 billion tones of crude steel produced in 2013 as a worst case scenario generated up to 64 million tonnes of waste, so such growth has great significance for waste managment.

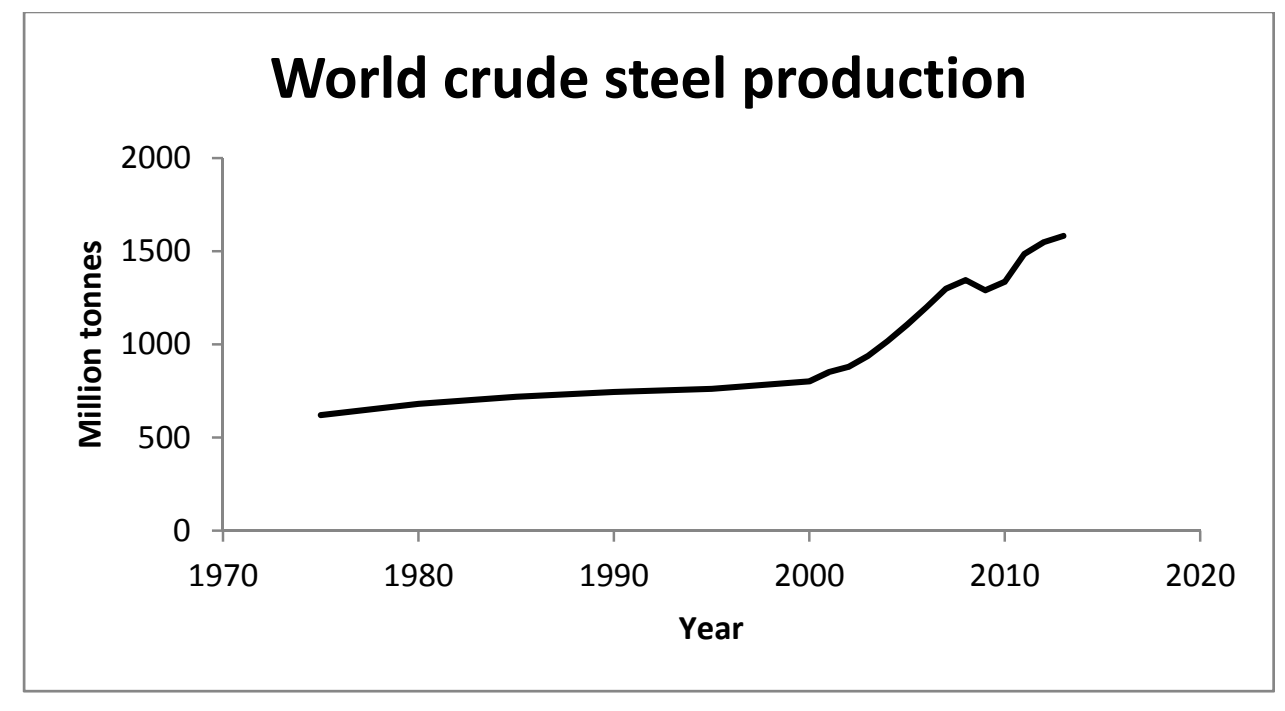

Figure 1. Crude steel produced between 1970-2013 (adapted from World steel [2]).

Increasing financial pressure on waste producers include annual increases in landfilling costs [19-20], more stringent regulatory thresholds, and increased financial penalties. These have been designed to reduce the attractiveness of landfill disposal options [7,8,19]. This has stimulated the need to investigate alternative solutions for sustainable resource use, to reduce the cost and environmental pollution, increase resource utilization and reduce waste generation. This is particularly the case with solid wastes due to the difficulty of characterizing them and identifying the hazardous fractions present that could be treated.

Screening tools that enable the producers and regulators of wastes to better understand the reactivity waste constituents would allow for effective ("smarter") decision making, because it would provide more detailed information about the likely fate of wastes in the environment and the potential for resource recovery. Measurement of total PTE concentrations is commonly used as a basis for the prediction of environmental impact, but for many constituents environmental reactivity is poorly related to total content $[12,20,21]$. Thus total PTE analysis can be considered a "worst case scenario" approach and risks classifying relatively inert materials in higher risk categories, with a commensurate financial burden. Easily soluble contaminants are identified with leaching-based methods such as WAC testing (see below); however this does not provide environmentally realistic predictions. For example, commonly-used simulations do not even emulate natural rainfall, which is a mildly acidic solution, this is particularly the case for soils, however it was suggested that the use of synthetic acid rain as opposed to distilled water was not necessary for municipal wastes because of the because of the high alkalinity 
of the municipal solid wastes [22]. Longer term reactivity tests supplemented by buffering data may be useful, but can be less attractive due to operational complexity and time dependent feedback.

The ability to chemically speciate toxic components, wih regards to phase association, in wastes provides crucial information about the solid-phase or dissolved species hosts for PTEs. This allows for better prediction and understanding of an element's environmental fate and potential impact [23]. However, precise speciation is often time-consuming or requires expensive analytical facilities, so sometimes the development of indirect proxies for characterisation is necessary. This is discussed further in Section 1.3 below.

\subsection{Regulatory Testing}

Waste Acceptance Criteria (WAC) is the compliance test implemented in July 2005 under the Landfill Regulations Amendment; England and Wales [24]; and Scotland [25], used within the UK for classification of materials. This is a leaching method (using water) that is implemented throughout Europe based on European Standard [26] that is adopted by EU states providing that they meet regulatory thresholds based on hazardous limits set for waste disposal by an EU Council Decision [27].

There are four variations of the EN standard 12457 (e.g., 12457-1, 12457-2, etc.): Part 1 is a single stage batch test $2.0 \mathrm{~L} / \mathrm{kg}$ water-waste ratio; part 2 is a single stage batch test at $10.0 \mathrm{l} / \mathrm{kg}$ ratio; part 3 is a two-stage batch test using both $2.0 \mathrm{~L} / \mathrm{kg}$ and $8.0 \mathrm{~L} / \mathrm{kg}$, and part 4 is a single batch test with $10.0 \mathrm{~L} / \mathrm{kg}$ ratio but with particle sizes below $10 \mathrm{~mm}$ (1-3 specify particle size below $4 \mathrm{~mm}$ ). Within the EU, individual countries have adopted this procedure (Table 1) as a routine testing protocol. It can be seen that the UK has no set routine procedure, however WAC testing is used with a corresponding guidance document [28]. The WAC specifies leaching limit values defined by the Acceptance Leaching Test (BS EN 12457 [29]) based upon parameters that include total solid concentration, moisture content, leached content, $\mathrm{pH}$ and $\mathrm{Eh}$ that are used to assess risk to the environment and ultimately establishes the potential for their disposal, removal or recovery.

Table 1. Use of EU standard "EN 12457" in European countries, including variations in approaches to use and implementation [30].

\begin{tabular}{ccccc}
\hline Country & $\begin{array}{c}\text { Regulation of The } \\
\text { Use of Waste } \\
\text { Aggregate? }\end{array}$ & $\begin{array}{c}\text { Criteria on Total } \\
\text { Content? }\end{array}$ & $\begin{array}{c}\text { Criteria on } \\
\text { Leaching } \\
\text { Content? }\end{array}$ & $\begin{array}{c}\text { Type of } \\
\text { Leaching Test }\end{array}$ \\
\hline Austria & Guidelines & Yes & Yes & $\begin{array}{c}\text { EN 12457-4 } \\
(\mathrm{L} / \mathrm{S}=10.01 / \mathrm{kg})\end{array}$ \\
Czech republic & $\begin{array}{c}\text { Based on landfill } \\
\text { legislation }\end{array}$ & Yes & Yes & EN 12457-4 \\
Denmark & Yes & Yes & Yes $10.01 / \mathrm{kg})$ \\
Finland & Yes & Yes & Yes & EN 12457-1 \\
France & Yes & Yes & Yes & CEN/TS 14405 $12457-2$ and 4 \\
\hline
\end{tabular}


Table 1. Cont.

\begin{tabular}{|c|c|c|c|c|}
\hline Country & $\begin{array}{c}\text { Regulation of The } \\
\text { Use of Waste } \\
\text { Aggregate? }\end{array}$ & $\begin{array}{c}\text { Criteria on Total } \\
\text { Content? }\end{array}$ & $\begin{array}{c}\text { Criteria on } \\
\text { Leaching } \\
\text { Content? } \\
\end{array}$ & $\begin{array}{c}\text { Type of } \\
\text { Leaching Test }\end{array}$ \\
\hline Germany & $\begin{array}{l}\text { Yes (new reg in } \\
\text { preparation) }\end{array}$ & Yes & Yes & $\begin{array}{c}\text { EN 12457-2 } \\
\text { (\& new leg. DIN } \\
19528)\end{array}$ \\
\hline Italy & Yes & No & Yes & EN 12457-2 \\
\hline Spain & Yes-by region & No & Yes & $\begin{array}{c}\text { EN 12457-4 } \\
(\& \text { Din 38414-s4) }\end{array}$ \\
\hline United Kingdom & $\begin{array}{l}\text { Case by case } \\
\text { guidance }\end{array}$ & No & No & $\begin{array}{l}\text { Variable — no set } \\
\text { routine }\end{array}$ \\
\hline
\end{tabular}

Criteria on: total content or leaching content refers to whether each country includes data of the different chemical measurements.

Although many countries within the EU apply EN 12457 [29] or a similar, or more stringent screening processes, there are still problems with the testing scheme itself. A key issue not currently addressed is the stability of PTEs once leached out, and whether precipitation can occur [12].

The chemistry of the contaminants of interest can be difficult to evaluate with leaching tests due to the compounds or complexes in which they are hosted. Although no consideration is given to speciation of the contaminants of interest in WAC and similar leaching tests, it is known that this can affect solubility under specific conditions [31]. Consequently, this may affect rates dissolution and precipitation and, where there is a high organic matter content, rates of adsorption and desorption. Speciation may also influence the mobility, bioavailability and ultimately the potential for toxic effects within the wider environment [12].

Despite its limitations, WAC testing dictates landfill disposal routes for wastes (hazardous, non-hazard and inert) that not only come with high costs but are becoming more restrictive for producers as threshold limits reduce [32]. Developing a tool to improve industrial management is required to be able to over come these ever growing constraints.

\subsection{Significance of Speciation}

Prediction of the fate of the PTEs on disposal can be established by studying the environmental conditions surrounding landfills and within waste deposits in order to establish how trace elements that are incorporated in the waste combine and interact with phases in the surrounding soil [33]. A further key factor in determining the fate of PTEs is their chemical form, which combines with the environmental factors to influence their mobility or stability. Chemical form and distribution of an element may both be refered to as its "speciation". IUPAC (International Union of Pure and Applied Chemistry) defines "speciation" in three ways:

- The specific form of an element, such as, its electronic or oxidation state, complexation, molecular structure or isotopic composition.

- The distribution of an element amongst defined chemical species in a system. 
- Analytical procedures for identifying and/or measuring the quantities of one or more individual chemical species in a sample.

These three definitions, when combined, provide a complete speciation of elements [23].

In steel wastes, the main constituents that cause "hazardous" classification are PTEs $(\mathrm{Pb}, \mathrm{Zn})$ and alkali metals (e.g., K), due to their concentration and potential environmental impact. The environmental impacts of these constituents depend strongly on their mineralogical and chemical form, as these dictate their mobility and bioavailability [34]. The ability to speciate in solid matrices analytically is often a difficult and complex process. However, the benefit from this knowledge concerning mobility and bioavailability of the elements of interest may provide better understanding and routes to the minimization of environmental impact [17].

If a fundamental understanding of the chemical and physical characteristics of PTEs found within wastes arising from the steel industry can be established, then a more informed and appropriate approach can be implemented for their removal, stabilization and/or re-use [35]. For example, in baghouse dusts collected from electric arc furnaces the main zinc phase present is known to be zinc ferrite $\left(\mathrm{Zn}_{\mathrm{x}} \mathrm{Fe}_{3-\mathrm{x}} \mathrm{O}_{4}\right)$, but hydrometallurgical cleaning techniques struggle to digest this compound [36]. With the use of synchrotron analytical technology both amorphous and crystalline zinc structures have been identified in blast furnace sludge (BFS). These include Zn phyllosilicates, Zn sulphide minerals (e.g., sphalerite, würtzite), KZn-ferrocyanide phases, hydrozincite and tetrahedrally coordinated adsorbed Zn, all having different stabilities and key reactivity characteristics [11]. These different $\mathrm{Zn}$ hosts are specific to individual waste types because the steel production process is inherently variable; the semi-continuous batch process varies from site to site due to different operational configurations and specialist production demands.

The ability to apply a single characterisation technique to a solid sample and obtain full speciation may be desirable when attempting to understand the fate of PTEs from wastes, however it is not always practical, economic or even possible. Nevertheless, relevant information can be inferred by establishing characteristic chemical traits of the waste under simulated environmental conditions. One such approach is sequential extraction.

\section{Sequential Extraction (SE) as a Technique for Waste Characterisation}

It is widely known that the application of strong acid leaching can be used to determine the total content of PTEs in solid phases but results in an overestimation for environmental exposure. Varying acid or other reagents sequentially by increasing strength or type (i.e., acidity or dissolution ability), can result in the successive solubilisation phases and release of associated elements from operationally defined fractions in the samples [37]. This approach is known as sequential extraction (SE) [38-41], originally applied to soils and sediments $[12,42]$. This technique can aid speciation by understanding the reaction behaviour of individual solid phases (fractions) as their presence may be inferred from their dissolved products in leachates extracted. SE also has an advantage over WAC water leaching as it provides a more realistic prediction of elemental mobility within the environment as extraction reagents are applied in to mimic environmental processes e.g., acid rain [43].

In the following sections we provide a detailed overview of SE methodologies and thus identify the current status of SE and its potential for application to successfully characterise different forms of steel 
waste. We conclude that this technique shows promising potential for its application within the waste management process.

\section{Wastes from the Steel Industry}

Wastes from steel production contain a range of potentially toxic elements (PTEs). The levels of risk that these present to environmental and human health are mitigated through processes such as dilution, dispersion, oxidation, degradation or sequestration into soils and sediments [44]. The sources of waste streams in the steel making process determine and the nature of the phases making up the bulk composition and hence their content of harmful materials.

\section{Nature of Wastes}

Steel is an alloy of iron and carbon, with other constituents such as lead, zinc, manganese, phosphorus, nickel, silicon, sulphur and chromium present at significant concentrations as impurities (from feedstock) or that have been added at various stages of the process [45]. Its production begins with a sinter plant, where the raw feed (e.g., limestone, coke feed, olivine, hematite, magnetite and recycled materials from the blast furnace (BF) and basic oxygen furnace (BOF) are mixed and heated to high temperatures as a pre-treatment process [46,47], resulting in the production of sinter. This is then heated in the $\mathrm{BF}$ to temperatures above $1000{ }^{\circ} \mathrm{C}$ with iron ore, and the addition of coke and limestone. Here, the coke is burnt to produce carbon monoxide, which is a key reducing agent, that in turn reduces the iron ore oxide as it travels up the shaft to iron [48]. Finally the molten pig iron from the BF and ferrous scrap (up to $30 \%$ ), are refined into steel by injecting a jet stream of high-purity oxygen (HPO) through the hot metal [49].

These high-temperature processes create significant quantities of sludge, slag, and dust that may generate toxic and hazardous by-products as well as valuable metals [50]. Such waste types are generated at different production points with different physical characteristics: Sludge is a semi-solid material consisting of fine particulate material $(0.02-0.3 \mathrm{~mm})$ collected during the purifying of BF gases, and flue dusts with the addition of water [51]. Dusts have the finest particles $(>200 \mu \mathrm{m})$ and are collected by extraction and gas cleaning systems [52]. Slag is a heterogeneous, porous material generated as a by-product of the impurities that are solidified during the BF process [43]. The concentrations of these constituents can vary depending on the type of waste and its intended use (Table 2: "bulk composition" refers to constituents contributing significant portion of the bulk mass).

Table 2. Illustrative bulk composition of steel wastes with example of variations observed in the literature $[43,53]$.

\begin{tabular}{cccccc}
\hline Dust [54] & $\mathbf{C a O}(\mathbf{1 - 5 \% )}$ & $\mathbf{S i O}_{2}(\mathbf{6 \%}-\mathbf{9 \%})$ & $\mathbf{M g O}(<\mathbf{2 \% )}$ & $\mathbf{A l}_{2} \mathrm{O}_{3}(\mathbf{2 \%} \mathbf{2 \%}-\mathbf{6 \%})$ & $\mathbf{P}_{2} \mathbf{O}_{5} \mathbf{n} / \mathbf{a}$ \\
\hline $\begin{array}{c}\text { Slag } \\
{[43,55]}\end{array}$ & $\mathrm{CaO}(30 \%-60 \%)$ & $\mathrm{SiO}_{2}(10 \%-35 \%)$ & $\mathrm{MgO}(1 \%-6 \%)$ & $\mathrm{Al}_{2} \mathrm{O}_{3}(0.5 \%-4 \%)$ & $\mathrm{P}_{2} \mathrm{O}_{5}$ \\
$\begin{array}{c}\text { Sludge } \\
{[54,56,57]}\end{array}$ & $\mathrm{CaO}(6 \%-14 \%)$ & $\mathrm{SiO}_{2}(2 \%-10 \%)$ & $\mathrm{MgO}(<0.1 \%)$ & $\mathrm{Al}_{2} \mathrm{O}_{3}(<0.1 \%)$ & $\mathrm{P}_{2} \mathrm{O}_{5}(<0.01 \%)$ \\
\hline
\end{tabular}


Table 2. Cont.

\begin{tabular}{|c|c|c|c|c|c|c|}
\hline Dust [54] & $\mathrm{TiO}_{2} \mathbf{n} / \mathbf{a}$ & $\mathrm{Fe}(48 \%-52 \%)$ & $\begin{array}{c}\mathrm{K}_{2} \mathrm{O} \\
(0.1 \%-2 \%)\end{array}$ & $\mathrm{Na}_{2} \mathrm{O}$ n/a & $S \mathbf{n} / \mathbf{a}$ & $\begin{array}{c}\mathrm{C} \\
(29 \%-34 \%) \\
\end{array}$ \\
\hline $\begin{array}{c}\text { Slag } \\
{[43,55]}\end{array}$ & $\mathrm{TiO}_{2}(0.4 \%-2 \%)$ & $\mathrm{Fe}(7 \%-80 \%)$ & $\mathrm{K}_{2} \mathrm{O}$ n/a & $\mathrm{Na}_{2} \mathrm{O}$ n/a & $\mathrm{S}(<0.1 \%)$ & \\
\hline $\begin{array}{c}\text { Sludge } \\
{[54,56,57]}\end{array}$ & $\mathrm{TiO}_{2} \mathrm{n} / \mathrm{a}$ & $\mathrm{Fe}(8 \%-66 \%)$ & $\mathrm{K}_{2} \mathrm{O} \mathrm{n} / \mathrm{a}$ & $\mathrm{Na}_{2} \mathrm{O}$ n/a & $\mathrm{S}(<1.5 \%)$ & $\begin{array}{c}\mathrm{C} \\
(7 \%-40 \%)\end{array}$ \\
\hline
\end{tabular}

NB: $\mathrm{Fe}$ refers to various $\mathrm{Fe}$ forms $\mathrm{FeO}$ and $\mathrm{Fe}_{2} \mathrm{O}_{3}$.

By identifying the key components of the different wastes, predictions can be made about the chemical structures present and how it affects reactivity in the environment. The main amorphous component of slags is glass, whilst crystalline constituents present are $\mathrm{Fe}, \mathrm{Ca}$, and $\mathrm{Mg}$ oxides, hydroxides, silicates and carbonates, with elemental Fe and quartz [43]. When exposed to simulated environmental conditions (water vapour saturated air current passed over and through slag) the formation of carbonate phases occurs that reduces the leaching of alkaline earth elements e.g., $\mathrm{Ca}, \mathrm{Mg}$ and $\mathrm{Cr}$ (VI and III) [58]. Phases in BF wastes are composed predominately of silica and alumina derived from mineral impurities in original iron ore, along with $\mathrm{Ca}$ and $\mathrm{Mg}$ oxides from added fluxes [59]. This combined with its finely particulate structure and exposed internal surface area can result in chemical reactions taking place and can alter porosity and permeability e.g., by corrosion or precipitation, which has been shown to significantly decrease the leaching of metals [51].

Elements of particular interest with respect to the environmental and industrial processing impact (Table 3) include potassium, lead and zinc, which are all known to be toxic to some degree depending on their chemical form. However, they are not typically assessed in regulatory analysis [60]. These constituents are problematic due to their potential toxicity, but they may also be "poisonous" to the production process [61], which can degrade the potential for recycling in the production cycle.

Table 3. Typical composition of key constituents of steel wastes (mass \%).

\begin{tabular}{cccccc}
\hline & $\begin{array}{c}\text { Sinter Dust } \\
{[\mathbf{6 2}]}\end{array}$ & $\begin{array}{c}\text { BOF Sludge } \\
\text { [61] }\end{array}$ & $\begin{array}{c}\text { BF Sludge (Gas } \\
\text { Treatment) [61] }\end{array}$ & $\begin{array}{c}\text { BF Sludge } \\
\text { (Dry) [63] }\end{array}$ & $\begin{array}{c}\text { BF Sludge (from } \\
\text { Landfill) [57] }\end{array}$ \\
\hline $\mathrm{Fe}$ & $43-50$ & $48-70$ & $7-35$ & $21-32$ & $5.7-27.5$ \\
$\mathrm{C}$ & $2.9-6.12$ & $0.7-4.6$ & $15-47$ & $1.0-3.2$ & $7-40$ \\
$\mathrm{~Pb}$ & $0.09-5.98$ & $0.04-0.14$ & $0.8-2$ & $0.3-1.2$ & $0.1-2$ \\
$\mathrm{Zn}$ & $0.03-0.34$ & $0.2-4.1$ & $1-10$ & $1.0-3.2$ & $1.5-8.6$ \\
$\mathrm{~K}$ & $3-9.07$ & $\mathrm{n} / \mathrm{a}$ & $0.08-0.36$ & $\mathrm{n} / \mathrm{a}$ & $0.1-1.7$ \\
$\mathrm{Ca}$ & $7.55-7.83$ & $3.0-17$ & $3.5-18$ & $\mathrm{n} / \mathrm{a}$ & $3.5-13.5$ \\
\hline
\end{tabular}

\section{Sequential Extraction}

Sequential extraction is a common analytical method used to identify elements associated with solid phases in environmental media on the basis of their reactivity with specific solutions. It has been applied to the analysis of sediments since the early 1980s [64-69], and since then has been applied to soils [70-72] and waste materials $[73,74]$.

This method establishes the environmental reactivity of PTEs by progressively applying a series of chemical reagents that are selected to release elements of interest associated with the respective phases, 
resulting in the fractionation of the element distribution in samples $[75,76]$. The extracts are separated from the sample and analysed directly, usually by atomic spectroscopy techniques for the elements of interest. The fraction of an element associated with each extraction step is compared to the "total" sample content obtained by a bulk chemical analysis of the sample. The sum of component fractions should equal an independently determined total value [77]. This technique could aid speciation by characterising steel wastes in accordance to fractions (phase associations).

Direct methods for more routine determination of solid-state speciation e.g., SEM, XRD, FTIR, are potentially of great value in characterizing waste materials, they can demonstrate intermediate to short scale variability, but are generally of insufficient sensitivity for environmental trace analysis or require multiple units of fairly specialized equipment to add sufficient new information for useful characterisation [78].

\subsection{Obstacles to the Application of SEP}

Sequential extraction is limited by the fractionation processes displacing chemical elements from a range of compounds resulting in chemical alteration of the matrix and potentially falsely indicating the presence of particular chemical phases in the sample. Furthermore this approach is not considered a fully quantitative method for the following reasons: the analyte may be re-distributed among solid phases during each extraction step rather than being extracted with the aqueous leachate; the reagents may not be sufficiently selective for the target phase; extraction may be inefficient and hence incomplete. In addition, new solid phases may be precipitated from the leachate [12]. The latter is also known to be a problem with other aqueous extraction methods such as WAC testing and is therefore common across all extraction protocols. The verification of "success" of SE protocols can be through the agreement of summed fractions with independent totals. These methods are also susceptible to particle loss during sample handling, particularly the loss of fine sample material when separating each fraction during centrifuging, decanting and washing. Typically only the leachate is analysed due to the destructive nature to the solid material, whereas when used together with solid-state analysis e.g., X-ray absorption spectroscopy sample integrity can remain in tack and the additional solid phase analysis can provide a more reliable outcome, for example predicting long term efficiency of in situ soil treatments [33].

The aggregation state of the sample may also cause inefficiencies in extraction. For example, mineral or organic coatings on sample particles, or other textural characteristics of multiphase particles, may prevent access of the reagent to some constituents. This could be overcome by crushing or grinding the sample. However, this can expose fresh mineral faces/surfaces with a different leaching response and metal release compared to matrices in real environmental conditions [12].

\subsection{Defining Fractions}

SE attempts to extract metals of interest by targeting pre-defined solid-state fractions of the sample having particular physico-chemical characteristics. In other words, it is a process that fractionates the sample according to its solubility or reactivity. Fractionation in this sense may be defined as: "the process of classification of an analyte or a group of analytes from a specific sample according to physical (e.g., size, solubility) or chemical (e.g., bonding, reactivity) properties" [23]. This approach does not, strictly, "speciate" samples, but it identifies the associations of the different fractions with known 
elemental and chemical species. Importantly, this fractionation approach to sample characterisation attempts to emulate natural fractionation processes that may mobilise toxic species in the environment, so it has operational value in the identification of the environmental impacts of waste systems.

In evaluating metal fractionation in steel wastes, we may draw upon decades of research on metal mobility and fractionation in ground and surface water [79], soils and sediments [80] and sewage sludge [81]. In contrast, relatively little information is available on the leaching and extraction methods that have been applied to industrial waste materials. Overall, however, we may conclude that the success of fractionation is affected by the the strength of the metal-ligand bonds associated with each fraction [82], as well as variations in $\mathrm{pH}$, redox state, organic content and other environmental factors $[83,84]$.

The reagents used for extraction are selected to target metals that may be essential major components of major solid phases (e.g., major framework-forming cations in crystalline solids) and/or bound into, or adsorbed onto solid phases by particular modes of bonding. The resulting range of SE protocols addresses typical groups of extraction targets with a varying number of steps, and the use of different nomenclature to label the associated phases. Commonly defined fractions are the exchangeable fraction, which targets weakly adsorbed chemical species and can be referred to as water- or acid-soluble, this can also include free aqua ions, inorganic and organic complexes; the carbonate fraction, which can be included with, or separated from, the exchangeable fraction; the reducible fraction, which can be referred to as the fraction associated with Fe and Mn oxides; the organically bound (oxidisable) fraction, and the residual (silicate) fraction [12,84-87]. Such operationally defined fractions can be difficult to equate with "metals bound to specific phases" when the procedural steps are not indicated [12]; this is a critical omission in many studies. Previous research has shown that similarly labeled fractions may be derived from different experimental procedures for extraction [88], which can provide very different results $[71,89,90]$. Therefore the expectation of similar results is only valid when more detail is disclosed in the description of methodology, providing a more in-depth explanation of the operationally-defined steps (see Figure 2).

For all fractions, typical extraction reagents are presented in Table 4, and relate to studies of to soil/sediment matrices. Fractions are identified and measured according to the elements leached from the solid phase into solution. Different extraction reagents have been used (Table 4, Table 5 and Table 6), to target similar solid phases, however the justification of their use by linking to specific reaction mechanisms is not common in SE development. Very few studies justify reagent composition on the basis of evidenced solid phase reaction.

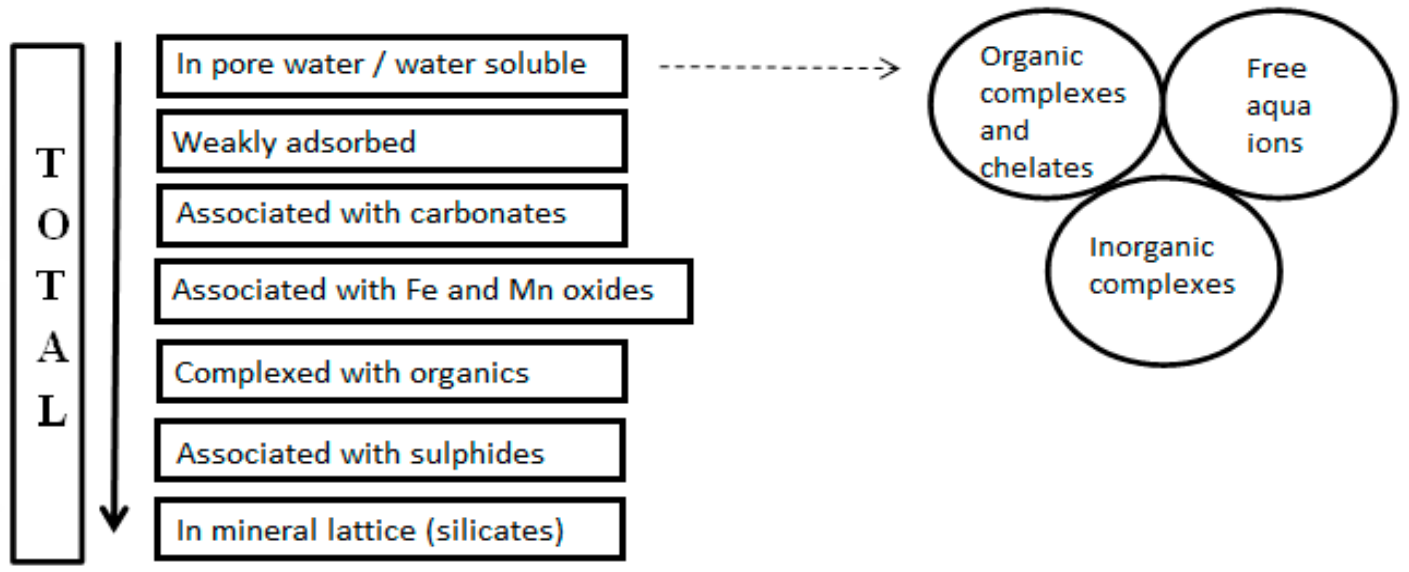

Figure 2. Chemical forms of metals in solid phases (Modified from [84]). 
Table 4. Modifications of BCR sequential extraction procedure (1993-2008).

\begin{tabular}{|c|c|c|c|c|}
\hline \multirow[t]{2}{*}{$\begin{array}{l}\text { Sample } \\
\text { Type }\end{array}$} & $\begin{array}{c}\text { Fraction } 1 \\
\text { (Exchangeable, Water } \\
\text { and Acid Soluble) } \\
\end{array}$ & $\begin{array}{c}\text { Fraction } 2 \\
\text { (Reducible (Fe and Mn-Oxyhydroxides) }\end{array}$ & $\begin{array}{c}\text { Fraction } 3 \\
\text { (Oxidisable-Organic Matter } \\
\text { and Sulphides) } \\
\end{array}$ & $\begin{array}{l}\text { Fraction } 4 \text { (Residual- } \\
\quad \text { Silicate Bound) }\end{array}$ \\
\hline & Reagents & Reagents & Reagents & Reagents \\
\hline $\begin{array}{l}\text { Soils and sediments } \\
\text { [41] }\end{array}$ & $\begin{array}{c}0.11 \mathrm{moL} \cdot \mathrm{L}^{-1} \text { acetic acid } \\
2 \mathrm{~h}[91]\end{array}$ & $\begin{array}{l}0.1 \mathrm{moL} \cdot \mathrm{L}^{-1} \text { hydroxyl-ammonium chloride } \\
\qquad \mathrm{pH} 2,4 \mathrm{~h}[91]\end{array}$ & $\begin{array}{l}\text { hydrogen peroxide followed by } \\
1.0 \mathrm{moL} \cdot \mathrm{L}^{-1} \text { ammonium acetate at } \mathrm{pH} 2\end{array}$ & aqua regia \\
\hline $\begin{array}{l}\text { Sewage sludge [92] } \\
\text { Sediment [68] }\end{array}$ & $0.11 \mathrm{moL} \cdot \mathrm{L}^{-1}$ acetic acid & $\begin{array}{c}0.5 \mathrm{moL} \cdot \mathrm{L}^{-1} \text { hydroxyl - ammonium chloride } \\
\mathrm{pH} 1.5\end{array}$ & $\begin{array}{c}\text { hydrogen peroxide followed by } \\
1.0 \mathrm{moL} \cdot \mathrm{L}^{-1} \text { ammonium acetate at } \mathrm{pH} 2\end{array}$ & aqua regia \\
\hline N/A [12] & $0.11 \mathrm{moL} \cdot \mathrm{L}^{-1}$ acetic acid & $0.5 \mathrm{moL} \cdot \mathrm{L}^{-1}$ hydroxyl-ammonium chloride & $\mathrm{H}_{2} \mathrm{O}_{2}, 1.0 \mathrm{moL} \cdot \mathrm{L}^{-1} \mathrm{CH}_{3} \mathrm{COONH}_{4}$ & Aqua regia \\
\hline Sewage sludge [93] & $\begin{array}{c}40 \mathrm{~mL} 0.11 \mathrm{M} \text { Acetic } \\
\text { acid }\end{array}$ & $\begin{array}{l}40 \mathrm{~mL} 0.10 \mathrm{M} \text { hydroxylamine hydrochloride } \\
\qquad\left(\mathrm{pH} 2 \mathrm{HNO}_{3}\right)\end{array}$ & $10 \mathrm{~mL} 8.8 \mathrm{M} \mathrm{H}_{2} \mathrm{O}_{2}$ AND $1 \mathrm{M}$ Acetic acid & $\mathrm{HF}$ \\
\hline Solid wastes [74] & $0.11 \mathrm{moL} \cdot \mathrm{L}^{-1}$ Acetic acid & $\begin{array}{l}0.1 \mathrm{moL} \cdot \mathrm{L}^{-1} \text { hydroxylamine hydrochloride } \\
\qquad\left(\mathrm{pH} 2 \mathrm{HNO}_{3}\right)\end{array}$ & $\begin{array}{c}1 \mathrm{moL} \cdot \mathrm{L}^{-1} \text { ammonium } \\
\text { acetate }(\text { adjusted } \mathrm{pH} \\
\left.\mathrm{HNO}_{3}\right)\end{array}$ & $\begin{array}{l}\text { Perchloric acid- } \\
\text { hydrofluoric acid, } \\
\text { hydrochloric acid. }\end{array}$ \\
\hline $\begin{array}{l}\text { Municipal sewage } \\
\text { sludge [81] }\end{array}$ & $\begin{array}{l}0.11 \mathrm{moL} \cdot \mathrm{L}^{-1} \text { and } \\
\mathrm{CH}_{3} \mathrm{COOH}\end{array}$ & $\begin{array}{l}0.5 \mathrm{moL} \cdot \mathrm{L}^{-1} \text { hydroxyl-ammonium chloride } \\
\mathrm{pH} 1.5\end{array}$ & $\begin{array}{l}\mathrm{H}_{2} \mathrm{O}_{2}, 1.0 \mathrm{moL} \cdot \mathrm{L}^{-1} \text { and } \\
\mathrm{CH}_{3} \mathrm{COONH} \mathrm{OH}_{4} \text { at pH } 2\end{array}$ & $\begin{array}{c}7 \mathrm{~mL} \mathrm{HNO}_{3}+2 \mathrm{~mL} \mathrm{HF}+ \\
1 \mathrm{~mL} \mathrm{HClO}_{4}\end{array}$ \\
\hline $\begin{array}{l}\text { Marine Sediments } \\
\qquad[94]\end{array}$ & $0.11 \mathrm{M}$ Acetic acid & $\begin{array}{l}0.10 \mathrm{moL} \cdot \mathrm{L}^{-1} \text { hydroxylamine hydrochloride } \\
\left(\mathrm{pH} 2 \mathrm{HNO}_{3}\right)\end{array}$ & $\begin{array}{c}30 \% \mathrm{H}_{2} \mathrm{O}_{2} \mathrm{pH} 2\left(\mathrm{HNO}_{3}\right) \text { AND } 1 \mathrm{M} \text { Acetic } \\
\text { acid } \mathrm{pH} 2\left(\mathrm{HNO}_{3}\right)\end{array}$ & Hot $\mathrm{HNO}_{3}$ conc. \\
\hline $\begin{array}{l}\text { Marine Sediments } \\
\text { [95] }\end{array}$ & $\begin{array}{l}20 \mathrm{~mL} 0.11 \mathrm{M} \text { Acetic } \\
\text { acid }\end{array}$ & $\begin{array}{l}20 \mathrm{~mL} 0.10 \mathrm{M} \text { hydroxylamine hydrochloride } \\
\left(\mathrm{pH} 1.5 \text { by addition of } 2 \mathrm{moL} \cdot \mathrm{L}^{-1} \mathrm{HNO}_{3} \text { ) }\right.\end{array}$ & $5 \mathrm{~mL} 8.8 \mathrm{M} \mathrm{H}_{2} \mathrm{O}_{2}$ AND $1 \mathrm{M}$ Acetic acid & $\mathrm{HNO}_{3}$ and $\mathrm{HF}$ \\
\hline $\begin{array}{l}\text { Marine Sediments } \\
\text { [69] }\end{array}$ & $\begin{array}{l}\text { Acetic acid } 0.11 \mathrm{moL} \cdot \mathrm{L}^{-1} \\
\text { pH } 2.85\end{array}$ & $\begin{array}{l}\text { Hydroxyl ammonium chloride }\left(\mathrm{NH}_{2} \mathrm{OH} . \mathrm{HCl}\right. \\
\left.0.1 \mathrm{moL} \cdot \mathrm{L}^{-1}\right) \mathrm{pH} 2\end{array}$ & $\begin{array}{c}30 \% \mathrm{H}_{2} \mathrm{O}_{2}\left(8.8 \mathrm{moL} \cdot \mathrm{L}^{-1}\right), \text { followed by } \\
\mathrm{CH}_{3} \mathrm{COONH}_{4}\left(1 \mathrm{moL} \cdot \mathrm{L}^{-1}\right) \\
\mathrm{pH} 2\end{array}$ & $\begin{array}{l}\text { Mix } \mathrm{HNO}_{3}(2 \mathrm{~mL}) \text { and } \\
\mathrm{H}_{2} \mathrm{O}_{2} \\
(2 \mathrm{~mL})+\mathrm{HF}(0.5 \mathrm{~mL})\end{array}$ \\
\hline
\end{tabular}


Table 5. Modifications of Tessier sequential extraction procedure (1979-2005).

\begin{tabular}{|c|c|c|c|c|c|c|c|}
\hline \multirow{3}{*}{$\begin{array}{c}\text { Sample Type } \\
\text { Tessier } \\
\text { (original) } \\
\text { fluvial } \\
\text { sediments [64] }\end{array}$} & \multirow{3}{*}{$\begin{array}{c}\text { Fraction } 1 \\
\text { Reagents } \\
\begin{array}{c}8 \mathrm{~mL} 1 \mathrm{M} \mathrm{MgCl} \\
\mathrm{pH} 7.0,1 \mathrm{~h}\end{array}\end{array}$} & \multirow{3}{*}{$\begin{array}{c}\text { Fraction } 2 \\
\text { Reagents } \\
8 \mathrm{~mL} 1 \mathrm{M} \mathrm{NaOAc}, \\
\begin{array}{c}\text { acetic acid to } \\
\text { pH } 5,6 \mathrm{~h}\end{array}\end{array}$} & \multirow{2}{*}{$\begin{array}{c}\text { Fraction } 3 \\
\text { Reagents }\end{array}$} & \multicolumn{3}{|c|}{ Fraction 4} & \multirow{2}{*}{$\begin{array}{c}\text { Fraction } 5 \\
\text { Reagents }\end{array}$} \\
\hline & & & & \multicolumn{3}{|c|}{ Reagents } & \\
\hline & & & $\begin{array}{c}20 \mathrm{~mL} 0.04 \mathrm{M} \\
\mathrm{NH}_{2} \mathrm{OH}-\mathrm{HCl} \text { in } \\
25 \%(\mathrm{v} / \mathrm{v}) \mathrm{HOAc}, 6 \mathrm{~h}\end{array}$ & $\begin{array}{c}3 \mathrm{~mL} 0.02 \mathrm{M} \\
\mathrm{HNO}_{3}, 5 \mathrm{~mL} \mathrm{30 \%} \\
\mathrm{H}_{2} \mathrm{O}_{2}(\mathrm{pH} 2 \text { with } \\
\left.\mathrm{HNO}_{3}\right), 65^{\circ} \mathrm{C}, 3 \mathrm{~h}\end{array}$ & $\begin{array}{c}3.2 \mathrm{M} \\
\mathrm{NH}_{4} \mathrm{OAc} \text { in } \\
20 \%(\mathrm{v} / \mathrm{v}) \\
\mathrm{HNO}_{3} \\
\end{array}$ & 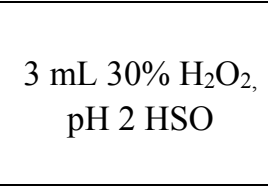 & $\mathrm{HF}-\mathrm{HClO}_{4}$ \\
\hline N/A. [12] & $1 \mathrm{M} \mathrm{MgCl}_{2}(\mathrm{pH} 7.0)$ & $\begin{array}{l}1 \mathrm{M} \mathrm{NaOAc}, \\
\text { acetic acid to } \\
\mathrm{pH} 2 \\
\end{array}$ & $\begin{array}{c}0.04 \mathrm{M} \\
\mathrm{NH}_{2} \mathrm{OH}-\mathrm{HCl} \text { in } \\
25 \%(\mathrm{v} / \mathrm{v}) \mathrm{HOAc}, 96^{\circ} \mathrm{C} \\
\end{array}$ & $\begin{array}{c}\mathrm{HNO}_{3} / \mathrm{H}_{2} \mathrm{O}_{2} \\
\left(85^{\circ} \mathrm{C}\right)\end{array}$ & Then & $\begin{array}{c}3.2 \mathrm{moL} \cdot \mathrm{L}^{-1} \\
\mathrm{NH}_{4} \mathrm{OAc} \text { in } 20 \% \\
(\mathrm{v} / \mathrm{v}) \mathrm{HNO}_{3}\end{array}$ & $\mathrm{HF}-\mathrm{HClO}_{4}$ \\
\hline MSW [96] & $\begin{array}{c}1 \mathrm{M} \mathrm{CH}_{3} \mathrm{COOH} / \\
\mathrm{CH}_{3} \mathrm{COONa} \\
\mathrm{pH} 5,5 \mathrm{~h}\end{array}$ & $\begin{array}{l}\mathrm{NH}_{2} \mathrm{OH}-\mathrm{HCl} 0.1 \mathrm{M}, \\
40 \mathrm{~mL}\end{array}$ & $\begin{array}{c}\mathrm{K}_{4} \mathrm{P}_{2} \mathrm{O}_{7} 0.1 \mathrm{M}, 20 \mathrm{~mL}, \mathrm{pH} 9.5 \\
20^{\circ} \mathrm{C}, 24 \mathrm{~h}\end{array}$ & $\begin{array}{r}\mathrm{NH}_{2} \mathrm{OH}-\mathrm{HCl} 0.04 \\
20 \mathrm{~mL}\end{array}$ & $\begin{array}{l}4 \mathrm{M} \text { in } \mathrm{CH}_{3} \mathrm{CC} \\
\mathrm{L}, 60^{\circ} \mathrm{C}, 6 \mathrm{~h}\end{array}$ & $\mathrm{OH} 25 \%$ & $\begin{array}{c}\mathrm{HNO}_{3}-\mathrm{HCl} \text { Conc } \\
12 \mathrm{~h} 20^{\circ} \mathrm{C}, 3 \mathrm{~h} \text { at } \\
105{ }^{\circ} \mathrm{C}\end{array}$ \\
\hline Soil [91] & $\begin{array}{c}1 \mathrm{M} \mathrm{MgCl}_{2} \\
\mathrm{pH} 7.0\end{array}$ & $\begin{array}{l}1 \mathrm{M} \mathrm{NaOAc} / \text { acetic } \\
\text { acid pH } 5\end{array}$ & $\begin{array}{c}0.04 \mathrm{M} \\
\mathrm{NH}_{2} \mathrm{OH}-\mathrm{HCl} \text { in } \\
25 \%(\mathrm{v} / \mathrm{v}) \mathrm{HOAc}\end{array}$ & $\begin{array}{c}0.02 \mathrm{M} \mathrm{HNO}_{3} \text { in } 30 \% \\
\mathrm{H}_{2} \mathrm{O}_{2} \mathrm{pH} 2\end{array}$ & $\begin{array}{r}3.2 \mathrm{M} \mathrm{Nl} \\
(\mathrm{v} /\end{array}$ & $\begin{array}{l}\mathrm{H}_{4} \mathrm{OAc} \text { in } 20 \% \\
\mathrm{HNO}_{3}\end{array}$ & \\
\hline $\begin{array}{c}\text { Marine } \\
\text { sediment } \\
{[94]} \\
\end{array}$ & $\begin{array}{l}1 \mathrm{M} \mathrm{MgCl}_{2} \\
\mathrm{pH} 7.0,1 \mathrm{~h}\end{array}$ & $\begin{array}{l}1 \mathrm{M} \mathrm{NaOAc} / \text { acetic } \\
\text { acid, } 5 \mathrm{~h}\end{array}$ & $\begin{array}{c}0.04 \mathrm{M} \\
\mathrm{NH}_{2} \mathrm{OH}-\mathrm{HCl} \text { in } 25 \%(\mathrm{v} / \mathrm{v}) \\
\mathrm{HOAc} 6 \mathrm{~h}-96^{\circ} \mathrm{C} \\
\end{array}$ & $\begin{array}{c}30 \% \mathrm{H}_{2} \mathrm{O}_{2} \mathrm{pH} 2 \\
\left(85^{\circ} \mathrm{C}\right), 5 \mathrm{~h}\end{array}$ & $\begin{array}{l}3.2 \mathrm{moL} \cdot \\
20 \%(\mathrm{v} / \mathrm{v}\end{array}$ & $\begin{array}{l}-1 \mathrm{NH}_{4} \mathrm{OAc} \text { in } \\
\mathrm{HNO}_{3}, 0.5 \mathrm{~h}\end{array}$ & Hot $\mathrm{HF}-\mathrm{HClO}_{4}$ \\
\hline Soil [97] & $\begin{array}{c}8 \mathrm{~mL} 0.5 \mathrm{M} \mathrm{MgCl}_{2} \\
\mathrm{pH} 7.0,20 \mathrm{~min}\end{array}$ & $\begin{array}{l}8 \mathrm{~mL} 1 \mathrm{M} \mathrm{NaOAc}, \\
5 \mathrm{~h}\end{array}$ & $\begin{array}{c}0.04 \mathrm{M} \\
\mathrm{NH}_{2} \mathrm{OH}-\mathrm{HCl} \text { in } 25 \%(\mathrm{v} / \mathrm{v}) \\
\mathrm{HOAc}, 6 \mathrm{~h}-96{ }^{\circ} \mathrm{C}\end{array}$ & $\begin{array}{r}3 \mathrm{~mL} 0.02 \mathrm{M} \mathrm{HN} \\
\mathrm{He} \\
5 \mathrm{~mL} 3.2 \mathrm{~N}\end{array}$ & $\begin{array}{l}\mathrm{O}_{3} \text { and } 5 \mathrm{~mL} \\
\text { eated } 2 \mathrm{~h} \\
\mathrm{M} \mathrm{NH}{ }_{4} \mathrm{Oac}, 0\end{array}$ & $\begin{array}{l}30 \% \mathrm{H}_{2} \mathrm{O}_{2} \\
5 \mathrm{~h}\end{array}$ & $\begin{array}{c}4 \mathrm{~mL} \text { conc. } \mathrm{HNO}_{3}, \\
\text { and } 2 \mathrm{~mL} \mathrm{HCl} \\
\text { Microwave }\end{array}$ \\
\hline Sediments [98] & $1 \mathrm{M} \mathrm{MgCl}_{2}, \mathrm{pH} 7$ & $\begin{array}{l}1 \mathrm{M} \mathrm{NaOAc} / \text { acetic } \\
\text { acid, pH } 5\end{array}$ & $\begin{array}{c}0.04 \mathrm{M} \\
\mathrm{NH}_{2} \mathrm{OH}-\mathrm{HCl} \text { in } \\
25 \%(\mathrm{v} / \mathrm{v}) \mathrm{HOAc}\end{array}$ & $30 \% \mathrm{H}_{2} \mathrm{O}_{2}$, & $\mathrm{pH} 2$ with $\mathrm{H}$ & $\mathrm{NO}_{3}$ & $\begin{array}{c}\mathrm{HF}+\mathrm{HClO}_{4}+ \\
\mathrm{HNO}_{3}\end{array}$ \\
\hline MSW [99] & $1 \mathrm{M} \mathrm{NH}_{4} \mathrm{Ac}, \mathrm{pH} 7$ & $1 \mathrm{M} \mathrm{NaAc}, \mathrm{pH} 5$ & $\begin{array}{c}0.1 \mathrm{M} \mathrm{NH}_{2} \mathrm{OH}-\mathrm{HCl} \\
\mathrm{pH} 2,12 \mathrm{~h}\end{array}$ & $40 \mathrm{~mL} 0.1 \mathrm{M}$ & oxalate buffe & r, $\mathrm{pH} 3$ & $\begin{array}{c}30 \% \mathrm{H}_{2} \mathrm{O}_{2}(\mathrm{pH} 3), \\
1 \mathrm{M} \mathrm{NH}_{4} \mathrm{Ac}(\mathrm{pH} 7), \\
12 \mathrm{~h}\end{array}$ \\
\hline $\begin{array}{l}\text { Soils (Galán) } \\
\text { [100] }\end{array}$ & $1 \mathrm{M} \mathrm{NH}_{4} \mathrm{OAc}, \mathrm{pH} 5$ & $\mathrm{n} / \mathrm{a}$ & $\begin{array}{c}0.4 \mathrm{M} \mathrm{NH}_{2} \mathrm{OH}-\mathrm{HCl} \text { in } \\
\mathrm{CH}_{3} \mathrm{OOH} 25 \%\end{array}$ & $\begin{array}{l}0.2 \mathrm{M} \mathrm{HNO}^{30 \% \mathrm{H}_{2} \mathrm{O}_{2} \mathrm{t}}\end{array}$ & $\begin{array}{l}3,30 \% \mathrm{H}_{2} \mathrm{O}_{2} \text {, } \\
\text { then another }\end{array}$ & $\begin{array}{l}\mathrm{pH} 2 \\
\mathrm{H}_{2} \mathrm{O}_{2}\end{array}$ & $\begin{array}{c}\mathrm{HF}, \mathrm{HNO}_{3}, \mathrm{HCl} \\
10: 3: 1\end{array}$ \\
\hline
\end{tabular}


Table 6. Sequential extraction application to industrial wastes with characteristics similar to steel making wastes (key observations identified, recoveries that are not quoted were either not stated, or based on the residual fraction being the assumed difference of the pseudo total and the preceding steps, i.e., residual fraction not experimentally measured).

\begin{tabular}{|c|c|c|c|}
\hline Sample & & Elements & Remarks \\
\hline $\begin{array}{l}4 \text { fractions } \\
{[101] 1990}\end{array}$ & Mining wastes & $\mathrm{Cu}, \mathrm{Cd}, \mathrm{Zn}, \mathrm{Pb}$ & $\begin{array}{l}\text { Low leachability in water was observed with majority of metals found in residual fraction. } \\
\mathrm{Zn} \text { showed high levels in the acid soluble, reducible and residual fractions. } \mathrm{Cu} \text { was found in } \\
\text { the oxidizable fraction and } \mathrm{Pb} \text { in the reducible fraction. }\end{array}$ \\
\hline $\begin{array}{l}\text { Adapted Tessier SEP } \\
\text { [102] } 1995\end{array}$ & $\begin{array}{l}\text { Municipal solid waste } \\
\text { incinerator ash }\end{array}$ & $\mathrm{As}, \mathrm{Cd}, \mathrm{Cu}, \mathrm{Hg}, \mathrm{Pb}, \mathrm{S}, \mathrm{Zn}$ & $\begin{array}{l}\text { The } \mathrm{pH} \text { of the resulting leachate is the greatest factor governing the concentration of metals in } \\
\text { solution. This out ways concentrations in the ash. }\end{array}$ \\
\hline $\begin{array}{l}\text { SE based on Tessier } \\
\text { [103] } 1996\end{array}$ & Scale, sludge & $\mathrm{As}, \mathrm{S}, \mathrm{Cu}, \mathrm{Cr}, \mathrm{Zn}, \mathrm{Pb}$ & $\begin{array}{l}\text { Both scale and sludge consisted mostly of oxides of } \mathrm{Si}, \mathrm{Al} \text { and } \mathrm{Fe} \text {. The sequential extraction } \\
\text { showed that } \mathrm{As}, \mathrm{Cu} \text { and } \mathrm{Zn} \text { were leachable under extreme conditions. }\end{array}$ \\
\hline $\begin{array}{l}5 \text { fractions } \\
{[104] 1996}\end{array}$ & Landfill liners & $\mathrm{Pb}, \mathrm{Ni}, \mathrm{Cd}$ & $\begin{array}{l}\text { A new method: combined } \mathrm{SE}-\text {-sorption isotherm analysis. } \mathrm{SE} \text { data indicated } \mathrm{Pb} \text { and } \mathrm{Ni} \text { were } \\
\text { principally in the acid soluble fraction, and } \mathrm{Cd} \text { was in the exchangeable fraction. }\end{array}$ \\
\hline $\begin{array}{l}\text { Sequential extraction } \\
{[105] 1998}\end{array}$ & Dust & $\mathrm{Pb}$ & $\begin{array}{l}\mathrm{SE} \text { revealed } \mathrm{Pb} \text { in exchangeable fraction was less than } 7 \% \text { and mildly acidic steps for the bulk } \\
\text { dusts collected. The finer particle size factions from these areas of smelter showed higher } \\
\text { percentages of exchangeable lead. }\end{array}$ \\
\hline $\begin{array}{l}\text { 5-step } \\
{[106] 2008}\end{array}$ & BOF Flying dust & $\mathrm{Zn}$ & $\begin{array}{l}\text { Reference materials were used to show } \mathrm{Zn} \text { species } \mathrm{ZnCl}_{2} \text { and } \mathrm{ZnSO}_{4} \text { extracted from the } \\
\text { exchangeable fraction, } \mathrm{ZnCO}_{3} \text { in carbonate fraction, and } \mathrm{ZnS} \text { from the reduced fractions. } \\
\text { Complications with selectivity to } \mathrm{ZnO} \text { as was released during the second and third extraction } \\
\text { step. So cant distinguish } \mathrm{ZnCO}_{3} \text { from } \mathrm{ZnO} \text {. }\end{array}$ \\
\hline $\begin{array}{l}\text { BCR } \\
{[107] 2008}\end{array}$ & Sludge & $\mathrm{Cd}, \mathrm{Cu}, \mathrm{Cr}, \mathrm{Ni}, \mathrm{Pb}, \mathrm{Zn}$ & $\begin{array}{l}\text { Different sludges shows BCR recovery between } 80 \%-100 \% \text {. SE a higher degree of } \\
\text { mineralisation and stabilisation can occur by its lowered metal bioavailability - predicted as a } \\
\text { result of the associated to the oxidisable and residual fractions. }\end{array}$ \\
\hline $\begin{array}{l}\text { Revised BCR } \\
{[108] 2013}\end{array}$ & Slag & $\begin{array}{l}\mathrm{Al}, \mathrm{As}, \mathrm{Ba}, \mathrm{Be}, \mathrm{Co}, \mathrm{Cr}, \mathrm{Cu}, \mathrm{Fe}, \mathrm{Hg} \\
\mathrm{Mn}, \mathrm{Mo}, \mathrm{Ni}, \mathrm{Pb}, \mathrm{Sb}, \mathrm{SE}, \mathrm{S}, \mathrm{V}, \mathrm{Zn}\end{array}$ & Showed significant recoveries $88 \%-109 \%$. \\
\hline $\begin{array}{l}\text { Tessier } \\
{[109] 2013}\end{array}$ & Bottom Ash & $\mathrm{Cu}, \mathrm{Cd}$, and $\mathrm{Zn}$ & $\begin{array}{l}\text { The results showed that the fractionation of } \mathrm{Cu}, \mathrm{Zn} \text { and } \mathrm{Cd} \text { varied among the different size } \\
\text { particles, and was greatly dependent on the intrinsic property of the metal species and their } \\
\text { transfer behavior in the furnace. }\end{array}$ \\
\hline $\begin{array}{l}\text { BCR } \\
{[110] 2015}\end{array}$ & BF Slag & $\begin{array}{l}\mathrm{Al}, \mathrm{Ba}, \mathrm{Co}, \mathrm{Cr}, \mathrm{Cu}, \mathrm{Fe}, \mathrm{Mn}, \mathrm{Mo} \\
\mathrm{Ni}, \mathrm{Pb}, \mathrm{S}, \mathrm{V}, \mathrm{Zn}\end{array}$ & Showed difficulties regarding $\mathrm{Zn}$ recovery during step 1 and $\mathrm{Cu}$ recovery during step 2 \\
\hline 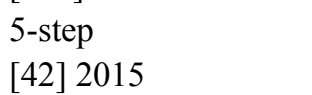 & BF Sludge & $\mathrm{Hg}$ & $\begin{array}{l}\text { Specifically optimised } \mathrm{Hg} \text { focused SEP that was proven successful for BFS with recoveries } \\
73 \%-114 \% \text { despite being optimised for soils. }\end{array}$ \\
\hline
\end{tabular}




\subsubsection{Exchangeable Fraction}

The exchangeable fraction, sometimes referred to as the acid-soluble/water soluble fraction, is envisaged to comprise water-soluble elements as well as ion $\left(\mathrm{H}^{+}\right)$exchangeable and carbonate bound metals. This fraction represents the natural environmental effects of acidic rainwater percolation [111]. These metals are also considered to be mobile and can be used to quantify the short term availability for leaching or uptake by plants [112]. They are removed from the solid phases (raw steel wastes) by electrostatic interactions and the changing ionic composition of water. This allows metals sorbed on exposed sediment surfaces to be removed easily by adsorption-desorption processes [100], thus ultimately by ion exchange.

Mobility and ease of extraction into the environment can depend on solubility. Metal hydroxide minerals have a low solubility under high $\mathrm{pH}$ conditions in water due to hydroxyl ion activity being inversely related to $\mathrm{pH}$. As $\mathrm{pH}$ decreases, solubility increases and more metals are liberated into solution [113]. In the aqueous environment the free sites are easily occupied my neutral salts [114].

In soils when heavily contaminated, many metals at high concentrations will form precipitates with oxides, hydroxides and carbonates, especially at higher $\mathrm{pH}$ [85].

The solid-phase hosts of his fraction can act as a major adsorbent in industrial sludge, providing a high bioavailability because any change in $\mathrm{pH}$ may affect the processes of adsorption-desorption and ultimately the mobility of metals [107]. The cation exchange capacity (CEC) is also an influencing factor, where silicate minerals can provide cation exchange (CE) sites for adsorption/desorption of the metals [115]. Typically, steel wastes contain 30\%-35\% silicates [60] and approximately 30\% for typical soils [116]; in soils these tend to predominately consist of phyllosilicates with a high CEC however steel wastes have a mixture with anhydrous and orthosillicates with a lower CEC. However, silicates in soils, when combined with their organic matter content, give a correspondingly higher joint cation exchange capacity [117] and therefore a greater affinity to retain metals.

In most soils the exchangeable fraction accounts for less than $2 \%$ of total metals with the exceptions of microelements $\mathrm{K}, \mathrm{Ca}$, and $\mathrm{Mn}$ [99].

As previously mentioned this fraction can be separated into a further fraction; the carbonate bound fraction. Carbonation by absorption of atmospheric $\mathrm{CO}_{2}$ and addition during any waste processing steps (such as by the addition of lime) results in significant carbonate abundance in many waste streams. This can lead to redistribution of element associations, but is dependent on physical properties. For example, it has been observed [107] that metal partitioning within sewage sludge is strongly influenced by stabilization treatments (whether by a chemical or mechanical approach), and when introduced to soil most of the metals will associate or complex with the carbonates present, despite the presence of other reactive phases. Larger particles are associated with higher contaminant concentrations and are more likely to be encased by carbonate coatings, hence reducing the efficiency of reagents and consequently are not redistributed between the sequential extraction steps [35].

\subsubsection{Reducible Fraction}

The reducible (Fe-Mn oxides) fraction represents metals bound to iron and manganese (and sometimes aluminium) oxides that would be released if the solid matrix were susceptible to anoxic 
(reducing) conditions [100]. It has been shown that the oxides often act like a cement between particles and form coatings on mineral surfaces particularly in soils, whilst fine particles can be present due to a combination of precipitation, adsorption, surface complex formation and ion exchange [20]. The extraction of the metals bound to this phase, whether as Fe-oxides, Mn-oxides or both, is dependent on the efficiency of the selected reagents used previously. For example it is possible that carbonates have not been completely dissolved in preceding steps. It is also possible that the content of Fe and $\mathrm{Mn}$ hydroxides is low and release would not be detected [111].

The process of adsorption/desorption is strongly dependent on $\mathrm{pH}$ and the availability of particulate surfaces to bind to. $\mathrm{Cd}$ and $\mathrm{Zn}$ for example have adsorption edges at higher $\mathrm{pH}$ 's compared to $\mathrm{Fe}$ and $\mathrm{Cu}$ and consequently are more mobile and widely dispersed $[81,85,118]$. This can occur as a combination of the precipitation, adsorption, surface complex formation and ion exchange [119]. Particle size varies greatly in steel wastes (see Table 7). This can can effect available surface areas, adsorption processes and 3 ultimately bioavailability [120]).

Table 7. Typical particle size distribution of industrial waste materials.

\begin{tabular}{|c|c|c|c|}
\hline Fly Ash & Flue Dust & BOF Sludge & BF Sludge \\
\hline $\begin{array}{l}\text { Size from } 0.5 \text { to } \\
\quad 300 \mu \mathrm{m}\end{array}$ & $\begin{array}{l}0.075-0.250 \mathrm{~mm} \\
\text { dominated in the } \\
\text { flue dust [121] }\end{array}$ & $\begin{array}{l}\text { From less than } 5 \mu \mathrm{m} \text { to as } \\
\text { large as } 1 \mathrm{~mm} \text { [122] }\end{array}$ & $\begin{array}{c}\text { Up to } 1.5 \mathrm{~mm} \\
\text { fine-grained } 1-10 \mu \mathrm{m} \\
\text { coarser part } 10-100 \mu \mathrm{m}, \\
\text { where } 90 \% \text { of particles are below } \\
50 \mu \mathrm{m}[53]\end{array}$ \\
\hline $\begin{array}{c}0.1-500 \mu \mathrm{m} \text { with } \\
\text { majority between } \\
20-60 \mu \mathrm{m}[123]\end{array}$ & $\begin{array}{l}\text { P50 of } 41.468 \mu \mathrm{m} \\
\text { P10 } 17.57 \mu \mathrm{m}, \text { P90 } \\
\text { was } 83.6 \mu \mathrm{m}[124]\end{array}$ & $\begin{array}{c}\text { Average particle size: } \\
\text { Fine fraction } \sim 37 \mu \mathrm{m}, \\
\text { Coarse fraction } \sim 210 \mu \mathrm{m} \\
{[125]}\end{array}$ & $\begin{array}{c}\text { Percentage distribution [126]: } \\
2-5 \mathrm{~mm}=13.65 \\
1.25-2 \mathrm{~mm}=32.53 \\
0.8-1.25 \mathrm{~mm}=15.56 \\
0.2-0.8 \mathrm{~mm}=20.2810 .40 \\
0.08-0.2 \mathrm{~mm}=10.20 \\
<0.08 \mathrm{~mm}=7.78\end{array}$ \\
\hline $\begin{array}{c}2 \mu \mathrm{m}-10 \mu \mathrm{m} \\
{[127]}\end{array}$ & & $\begin{array}{l}<0.7-43 \mu \mathrm{m} \text { range with } \\
\text { main fraction falling in } \\
14-22 \mu \mathrm{m} \text { fraction [128] }\end{array}$ & \\
\hline
\end{tabular}

Metals bound into oxide phases are considered stable. However, when incorporated with other compounds (e.g., by adsorption, desorption or ion exchange, etc.) in the environment they can be slowly released over time, or influenced by redox (reduction-oxidation) conditions [85]. Furthermore major cations such as $\mathrm{Mg}^{2+}$ and $\mathrm{Ca}^{2+}$ compete for sorption sites with other metals [113], which will be a major factor in BF wastes [60] as this can result in the liberation of its PTEs in the environment.

\subsubsection{Oxidisable Fraction}

The oxidisable fraction consists of organic- or sulphide-bound elements and metals. They may be complexed or peptised by natural organic substances. They can bind with functional groups such as carboxyl, phenol, alcohol, carbonyl and methoxyl [129]. In soils and sediments, these pollutants are assumed to remain within the solid matrix and are mobilized after a significant period of time, usually 
by the decomposition of organic matter, or are liberated when exposed to oxidising conditions [20,107]. The extracts obtained during this extraction step when dealing with steel wastes are typically metals bound to sulphides [130].

The most commonly used reagent for the extraction of metals in organic phases is hydrogen peroxide with ammonium acetate. However $\mathrm{HNO}_{3}$ with $\mathrm{HCl}$ has also been used to dissolve sulphides as it provides enhanced selectivity. However, this extraction mixture is aggressive towards silicates [131], and makes it less selective and unapplicable for preceeding steps e.g., exchangeable or reducible fraction.

The organic-bound fraction released in the oxidisable fraction SE step is considered not to be bioavailable due to the fact that it is associated with stable high molecular weight humic substances that release small amounts of metals slowly [132]. Metals can be adsorbed onto organic matter and mineral surfaces in inorganic and organic forms and transported throughout the environment [133], which is relevant to steel wastes when they are released to the wider environment.

\subsubsection{Residual Fraction}

The residual fraction is where metals have the strongest associations with crystalline structures of primary and secondary minerals, i.e., they are the most difficult to extract. This fraction is relevant in the assessment of long-term risk of PTEs [20].

The elements associated with this fraction are of little direct risk to the environment as the strong acids (e.g., concentrated $\mathrm{HCl}$ and $\mathrm{HNO}_{3}$,or both in aqua regia) used to leach in the extraction do not reproduce conditions that are ulikely to occur naturally [100]. These digestion techniques have potential to dissolve only a small amount of the silicate matrices (up to $20 \%$ content) and therefore naming this fraction the "silicate" phase is misleading, even if stronger digestion methods are used and partial solubility of silicate phases does occur.

The association of metal content with this fraction is defined by some authors as the difference between the pseudo-total concentration (strong acids - aqua regia) and the sum of the preceding fractions [134]. This may not be reliable due to summation error and the residual phase should strictly relate to complete dissolution (e.g., HF). However, the pseudototal is truly a maximum for many assessment purposes because achieving such extreme chemical conditions in the environment is highly unlikely. It should be recognized that in waste materials in particular, there may be a significant but highly inert portion of the elements of interest in this phase e.g., spinels.

\subsection{Contribution of SE to Sample Compositional Assessment}

The different fractions defined above can provide data relating to the reactivity and mobility (Table 7) of samples that can aid prediction of the fate PTEs within the environment. Identifying the characteristic traits of these fractions can assist indirectly in deriving likely speciation of elements in these waste materials.

\section{The Development of the Sequential Extraction Approach}

SE has been developed over the past 3-4 decades starting with a sequential extraction method originated by Tessier, Bison and Campbell in 1979 [64]. This is a 5-step procedure that separates element 
solid associations into exchangeable, acid soluble, reducible, oxidisable and residual fractions (Table 8). This basic scheme has been subjected to numerous modifications in order to increase reproducibility and efficiency of extraction [132,135]. This has been achieved by using different experimental conditions and extracting reagents [136-139].

Table 8. Relative mobility and availability of trace metals (modified from David, 1995 and Tessier $1979[64,84]$.

\begin{tabular}{|c|c|c|}
\hline Metal species and association & Description & Mobility \\
\hline Exchangeable (dissolved) cations & $\begin{array}{l}\text { fraction affected by ionic } \\
\text { composition, } \mathrm{pH} \text {, sorption } \\
\text { and desorption processes }\end{array}$ & $\begin{array}{l}\text { High. Changes in major cationic } \\
\text { composition (e.g., estuarine } \\
\text { environment) may cause a release due to } \\
\text { ion exchange }\end{array}$ \\
\hline $\begin{array}{l}\text { Metals associated with Fe-Mn } \\
\text { oxides (Reducible) }\end{array}$ & $\begin{array}{l}\text { consists of metals attached } \\
\text { to iron and manganese } \\
\text { oxides and which are } \\
\text { unstable under anoxic } \\
\text { conditions }\end{array}$ & $\begin{array}{l}\text { Medium. Changes in redox conditions } \\
\text { may cause a release but some metals } \\
\text { precipitate if sulfide mineral present is } \\
\text { insoluble }\end{array}$ \\
\hline $\begin{array}{l}\text { Metals associated with organic } \\
\text { matter (Oxidisable) }\end{array}$ & $\begin{array}{l}\text { can be released when the } \\
\text { organic matter is degraded } \\
\text { leading to release of soluble } \\
\text { metals under oxidizing } \\
\text { conditions }\end{array}$ & $\begin{array}{l}\text { Medium/High. With time, } \\
\text { decomposition/oxidation of organic } \\
\text { matter occurs }\end{array}$ \\
\hline $\begin{array}{l}\text { Metals associated with sulfide } \\
\text { minerals }\end{array}$ & $\begin{array}{l}\text { The sulfide minerals are a } \\
\text { class of minerals containing } \\
\text { sulfide }\left(\mathrm{S}^{2-}\right) \text { as the major } \\
\text { anion. }\end{array}$ & $\begin{array}{l}\text { Strongly dependent on environmental } \\
\text { conditions. Under oxygen-rich } \\
\text { conditions, oxidation of sulfide minerals } \\
\text { leads to release of metals }\end{array}$ \\
\hline $\begin{array}{l}\text { Metals fixed in crystalline phase } \\
\text { (Residual) }\end{array}$ & $\begin{array}{l}\text { Predominantly primary and } \\
\text { secondary minerals, which } \\
\text { may hold metals within } \\
\text { their structure }\end{array}$ & $\begin{array}{l}\text { Low. Only available after weathering or } \\
\text { decomposition }\end{array}$ \\
\hline
\end{tabular}

As previously mentioned the development of SEs' application developed a number of operational problems such as non-selectivity, redistribution of trace elements, re-adsorption, precipitation, extractant sufficiency and problems related to physical handling during sample preparation and drying techniques [111].

The original scheme was developed for the assessment of the potential impact of sediment bound PTEs on water quality [12]. However, the rapid extension to soils [140] and municipal solid wastes [99] resulted in significant modification of extraction steps and reagents which, in turn, made it difficult to compare data when evaluating results. The need for standardization resulted in research commissioned by the Community Bureau of Reference of the Commission of the European Communities (now called the European Community (EC) Standards Measurement and Testing Programme), which led to a harmonized three-stage, sequential extraction protocol known as "BCR" targeting the acid soluble, reducible and oxidisable fractions $[12,72]$.

The BCR method was validated using a sediment reference material (BCR-701) and sewage sludge amended soil (CRM-483) providing certified and indicative extractractable concentrations for $\mathrm{Cd}, \mathrm{Cr}$, $\mathrm{Cu}, \mathrm{Ni}, \mathrm{Pb}$ and $\mathrm{Zn}[92,128]$. This has been widely accepted as a reference standard [94,141-145] despite 
some shortcomings in the sequential extraction steps [146,147]. It is important to compare these methods: The biggest difference is the separation of extractable metal fractions, so that Tessier's first two steps equate to the total metal concentration in step one of BCR's method. This overlap is not distinct due to procedural differences including contact time, temperature and the solid to extractant volume ratio [132]. As with Tessier's method, the BCR SEP has been modified over time to optimise SE efficiency and success in fractionating a range of sample types (Table 4).

Unlike the temperature, which is frequently quoted in SEP reports (Tables 4 and 5), because it is considered a key operational parameter for reactivity; the extraction time or experimental length is not necessarily specified. Table 4 shows a variation of between $16-50 \mathrm{~h}$ and Table 4 only identifies the time period for only half of one method. The Galan procedure which incorporates both Tessier and BCR steps had a $14.5 \mathrm{~h}$ total extraction time and showed increased accuracy compared to the separate procedures [100]. The Geological Society of Canada (GCS) provides thorough detail of time requirements with a 5 step SEP totaling $21.2 \mathrm{~h}$ [148].

Insufficient contact time between the solid and the extracting reagent can be detrimental in ensuring complete extraction or the highest efficiency [149]. This can be considered a key factor when identifying the best procedural approach for industrial managers. It is worth noting that time constraints are not necessarily included in procedural descriptions, neither are the total separation time between steps. This means that the full resource implications of SEP application are not fully disseminated.

The continuous development of these procedures means no consistent extraction reagent list for the various components in sediment, soils and waste materials has been defined. This is exacerbated by matrix effects of different samples and the reagent "recipe" is strongly dependent on the waste composition. For example steel wastes are very base-rich compared to soils (see Tables 2 and 3 ), so there is a larger acid-buffering capacity during extraction [150].

\section{Key Factors Affecting the Effectiveness of SE}

The reason for the continuous modifications has been fuelled by the need to optimise the method for each different sample matrix. Factors that need to be considered include: the sequence of steps, specific matrix effects (such as cross-contamination), $\mathrm{pH}$ buffering, re-adsorption, precipitation, as well as physical characteristics (e.g., coatings, inclusions) of the various solid fractions [151].

A European framework project on the "Harmonisation of leaching/extraction tests" when comparing SE application to different solid materials (e.g., soils, sediments, mining wastes, fly ash, etc.), found that despite variation in matrix properties, the extraction processes were more consistent than would be anticipated [152], suggesting that matrix variation is not critical to method development in SE. The $\mathrm{pH}$ and buffering capacity of solids can greatly effect extraction and ultimately leaching efficiency (Figure 3). This has been considered in the context of the high $\mathrm{pH}$ of the water-soluble fraction, which leads to the formation of hydroxides that can result in the precipitation of metals. Although there is empirical evidence for part of the interaction with the leaching solution it is difficult to specify the phases involved. Previous research from Herck et al. [153] used a computer modelling program (Visual MINTEQ) to establish which minerals precipitate in terms of leaching efficiency as a function of $\mathrm{pH}$ (Figure 3). It can be seen that the higher the $\mathrm{pH}$ the lower the leached element, although above $\mathrm{pH} 12 \mathrm{~Pb}$ and $\mathrm{Zn}$ start to leach out again [154]. 


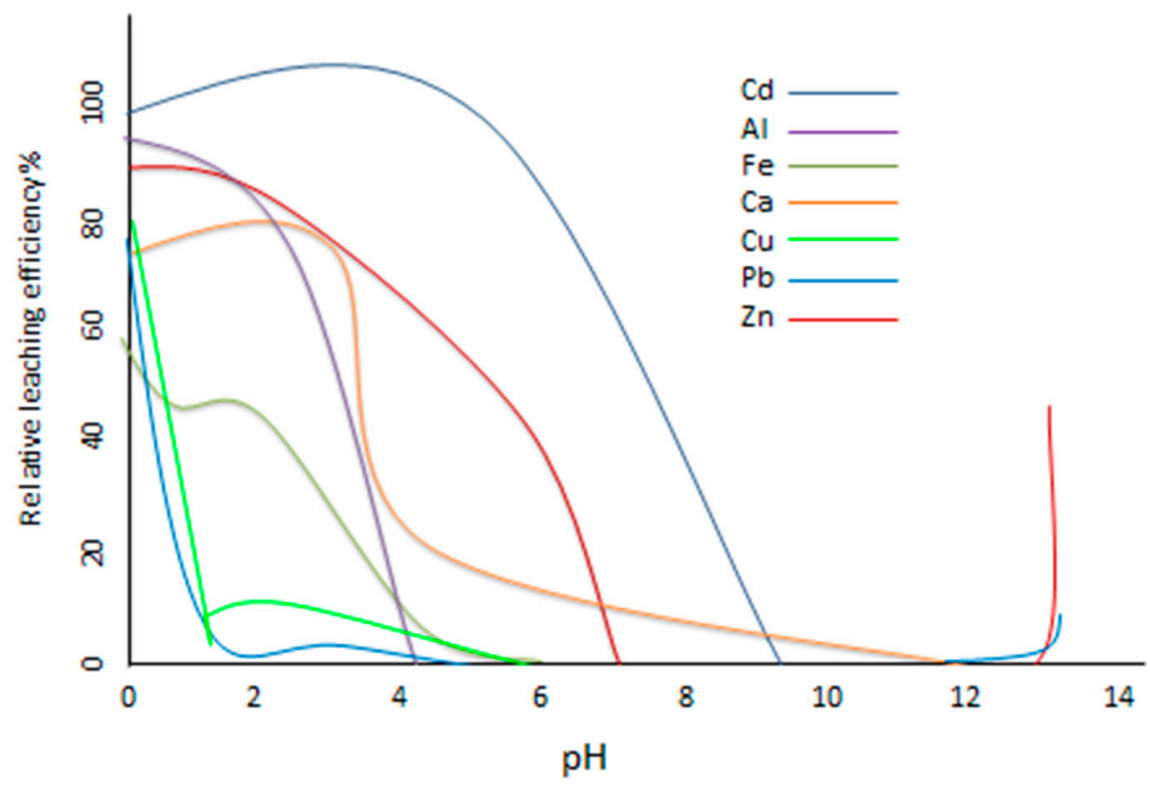

Figure 3. Relative leaching efficiency (\%) of elements as a function of the final $\mathrm{pH}$ for MSWI (municipal solid waste incinerator) fly ash [155].

Further investigation by comparison of modelled data and SE of fly ash was carried out to confirm necessary conditions to optimise extractions, with general agreement that it is successful $[150,153,155]$. This research highlighted fundamental information that needs to be considered when selecting a SE procedure. Zinc for example at $\mathrm{pH} 6$, has about $31 \%$ of its total concentration present in solution, and $26 \%$ is precipitated as smithsonite and $20 \%$ as $\mathrm{ZnO}^{-\mathrm{SiO}_{2}}$. At $\mathrm{pH} 4.5$, zinc solubility decreases due to the precipitation of zinc silicate; at $\mathrm{pH} 8$ different zinc minerals occur and no more zinc remains in solution and by $\mathrm{pH}>13.5$, zinc solubility increases again, due to the formation of hydroxide complexes [153].

Its application for modeling the speciation of steel slags has also been explored [156], showing unexpectedly that the key factors controlling the leaching of $\mathrm{Cr}$ and $\mathrm{Ba}$ are the presence of the mineral phases barite $\left(\mathrm{BaSO}_{4}\right.$ and hashemite $\left(\mathrm{Ba}(\mathrm{S}, \mathrm{Cr}) \mathrm{O}_{4}\right)$. It was also observed that the presence of $\mathrm{Na}$ made $\mathrm{pH}$ measurements unreliable and therefore elemental predictions could be inaccurate [155].

It can also be noted the considerable variation in $\mathrm{pH}$ of soil compared to fly ash and steel slag (Table 9) could suggest that using sequential extraction of fly ash as a reference matrix would be more relevant than that of data form soil extractions as they both have high alkaline properties that will consequently dictate the materials reactivity [157].

Table 9.Variation of $\mathrm{pH}$ in different sample matrices [157].

\begin{tabular}{ccccc}
\hline Variable & Soil & Steel Slag & BF Sludge [54] & Fly Ash \\
\hline $\mathrm{pH}$ & 3.9 & 12.5 & 9.88 & 13.1 \\
\hline
\end{tabular}

The majority of sequential extraction investigations are applied to sludge, sludge-amended soils, sediments and analysing the waste by-products that have leached or been composted into amended soils, whereas very few studies deal with direct applications to waste materials [96]. The literature on the application of SEP to more diverse waste materials is limited. The following section considers the major differences in material behaviour. 


\section{Application of SE to Different Wastes}

The applications of the Tessier and BCR schemes to steel waste analysis across the range of different sources are limited. However, waste matrices with similar characteristics have been observed including sewage sludge, fly ash, bottom ash and BF slag, all of which should exhibit similar effects due to similar characteristics such as particle size and elemental composition. These waste materials are often alkaline and contain solid phases able to adsorb and immobilize metals. Fly ash and steel slag, for example, have similar compositions that include calcium oxides, magnesium oxide, iron oxide, calcium silicates, calcium aluminates, and other silicates and oxides [157].

The appropriate reagents and experimental parameters are determined by assessing extraction success by its recovery (based on total recovered vs pseudo total digest) and based on the ability of its procedural steps to remove the desired analytes from specific phases [12].

Although the marjoity of examples throughout this review are soil and sediment focused there are examples of SEPs that have been successfully applied to different solid types Table 6 .

Although BCR is still widely used for sequential extraction (Table 4), it has been reported to show miss-classification for $\mathrm{Zn}$ during the first step and $\mathrm{Cu}$ in the second step when compared to certified materials for slags [110], sediments [158,159] and mining waste [17].

As previously noted, the lack of procedural detail in many descriptions and the wide range shown for those described more fully i.e., procedural steps; such as heating, contact time, etc., has been proven to be fundamental to the ability to successfully apply SEP [12]. Furthermore the percentage recoveries are often not stated and given experience of a number of intercomparison studies can make data difficult compare.

To be able to compare SE procedures applied to different samples other factors such as pH (Table 9) and particle size (Table 7). The reactivity of the sample matrix plays a vital role in the success of extraction, i.e., smaller particle size results in faster reactions.

BOF and BF sludge show that the particle size distribution can exceed $1.0 \mathrm{~mm}$ (Table 7) whereas flue dust and fly ash have a similar particle size that would suggest that these samples types could react in a similar manner. Therefore research showing characterisation (90-110) of fly ash could be a good starting point when deciding upon a SEP to adopt for steel flue dust characterisation. The physical and chemical properties of MSWI fly ash, such as particle size and chemical composition are known to influence the decomposition of metal host phases obtained by sequential extraction [153,160-163].

The comparison of the effectiveness of a SEP can be assessed by application in parallel to different industrial wastes, ensuring the same extraction reagents and operational steps are adhered to. A 7-step SEP was applied to extract metal fractions from mine wastes targeting seven operationally-defined phases: water-soluble, ion-exchangeable, carbonate, amorphous Fe-oxide, crystalline Fe-oxide, sulfide, and silicate [164]. The success of extraction was found to depend on particle size; a trend of increased concentration in $\mathrm{Fe}, \mathrm{Pb}, \mathrm{Zn}$ and $\mathrm{Cu}$ as the particle size of waste decreased particularly with water-soluble, Fe-MnOx $\mathrm{am}$ and sulphide fractions, and the inverse with the FeOx $\mathrm{x}_{\text {cryst }}$ attributed to the lack of dissolution of larger pyrite crystals [164].

This approach was further applied to operationally define metal associations in electric arc furnace dust (EAFD) [165] through the opportunity to provide more "complete" fractionation. Metals bound within spinel-type phases (residual fraction) were distinguished as a very stable component through the 
need for strong acid digestion. The six other steps are subject to sequential release of metals according to the conditions of solubility, $\mathrm{pH}$ and Eh.

SE can offer a higher resolution by the application of larger numbers of steps, also providing additional information, particularly when steel wastes are concerned. For example, the 7-step SE distinguishes between amorphous and crystalline Fe oxides/hydroxides. Logically, amorphous Fe will be more reactive in soil components as they represent a transition state between un-weathered parent materials and well-crystallized secondary soils minerals. These are also key forms of Fe found in steel waste; hematite $\left(\mathrm{Fe}_{2} \mathrm{O}_{3}\right)$ and goethite $(\mathrm{FeOOH})$ tend to occur as amorphous coatings on particles whereas transformation to crystalized Fe results in an irreversible hardening and altering the relative availability of associated elements [116].

\section{Conclusions}

As waste management regulations within Europe become more stringent and the option to landfill wastes becomes an increasingly unlikely future option, a critical need exists for industrial operators to assess the sustainability of the current production processes. Using SE to speciate the chemical composition of solids wastes provided higher resolution information to allow alternative uses or solutions for hazard reduction of wastes, whether it is stabilization for reclassification or extraction of valuable PTEs, which feeds back directly to production costs.

As no mandatory SEP exists, the options available for waste characterisation must be adopted on the basis of waste material properties. The consistency of approach is most critical. Although the BCR approach has been widely applied to a range of different sample types and a limited number of reference materials are available, the operational approach varies widely and in the case of wastes from the steel industry provides misleading data specifically with zinc, which is a critical constituent of wastes from all production processes. Tessier's procedure whilst having been historically the most applied has least methodological verification and typically has been applied to soils and sediments for a small array of elements.

SEP is an analytical tool that can provide a great detail of additional information relating to the environmental reactivity of solid samples. As an approach, it is far from routine, particularly in relation to speed of data collection. This is also true of other methods and may not be an issue where management plans are being developed. However, part of this relates to the poorly reported procedural data which suggests a variation in length of assay from a few hours to $2+$ days, not including separation time between steps. Its value lies in its efficiency to characterise waste types that can then be assessed for future treatment/stabilisation options. Characteristics that are found to be similar in other sample matrices, such as metal constituents, particle size and $\mathrm{pH}$ provide comparator opportunities for reference points. For example, soils have typically a larger maximum particle size (and wider size distribution range) and a significantly lower $\mathrm{pH}$, provide less chemically buffered conditions. Fly ash (which has been widely subject to a range of optimised SEP schemes) has similar characteristics to materials from steel processing e.g., pH steel slag 12.5 and Sludge 9.8, fly ash $\mathrm{pH} 13.1$ and may offer an opportunity of harmonization across a range of problem solid wastes. Steel waste management can benefit from the use of more complex SEPs as they offer a much higher resolution of the compositional detail. In particular the delineation of iron phases, which also has implications for more sustainable fly ash and mining waste 
management. Ultimately we note that the prospect for improved characterisation of steel wastes using $\mathrm{SE}$ is a viable step to advance industrial management procedures.

\section{Acknowledgments}

Acknowledgement goes to the University of West of Scotland for hosting this research, and financial sponsors Tata Steel Ltd. and ArcelorMittal.

\section{Author Contributions}

Andrew Hursthouse, Simon Cuthbertand Kiri J. Rodgers developed the concept for this review. Kiri J. Rodgers prepared drafts collected literature and undertook initial literature review. Andrew Hursthouse and Simon Cuthbert edited drafts prepared by Kiri J. Rodgers. All authors reviewed and edited the paper.

\section{Conflicts of Interest}

The authors declare no conflict of interest.

\section{References}

1. World Steel Association. World Steel in Figures 2013; World Steel Association: Brussels, Belgium, 2013.

2. World Steel Association. World Steel in Figures 2014; World Steel Association: Brussels, Belgium, 2014.

3. DSTGI. Management of Steel Plant Solid Wastes; Forecasting and Assessment Council: New Delhi, India, 2003.

4. Department for Environment Food \& Rural Affairs. Waste Legislation and Regulations; Department for Environment Food \& Rural Affairs: London, UK, 2015.

5. Environment Media Group Ltd. Lets Recycle; Environment Media Group Ltd.:London, UK, 2015.

6. Environment Media Group Ltd. Lets Recycle; Environment Media Group Ltd.:London, UK, 2012.

7. CEWEP. "Landfill Taxes \& Bans" Confederation of European Waste-to-Energy Plants. Available online: http://www.cewep.eu/media/www.cewep.eu/org/med_557/955_2012-04-27_cewep__landfill_taxes_bans_website.pdf (accessed on 1 June 2012).

8. Cointreau, S. Landfill ER Revenue versus Landfill Costs. World Bank: Washington, DC, USA, 2008.

9. Beratungsgesellschaft für Integrierte Problemlösungen. Services to Support Member StatesEnforcement Actions and Inspections Concerning the Application of EU Waste Legislation; European Commission: Brussels, Belgium, 2010.

10. Treating Waste as a Resource for the EU Industry. Analysis of Various Waste Streams and the Competitiveness of Their Client Industries; The European Competitiveness and Sustainable Industrial Policy Consortium: Rotterdam/Copenhagen, The Netherlands, 2013. 
11. Kretzschmar, R.; Mansfeldt, T.; Mandaliev, P.N.; Barmettler, K.; Marcus, M.A.; Voegelin, A. Speciation of $\mathrm{Zn}$ in blast furnace sludge from former sedimentation ponds using synchrotron X-ray diffraction, fluorescence, and absorption spectroscopy. Environ. Sci. Technol. 2012, 46, 12381-12390.

12. Bacon, J.R.; Davidson, C.M. Is there a future for sequential chemical extraction? Analyst 2008, 133, 25-46.

13. Van der Sloot, H.A. Horizontal standardisation of test methods for waste, secondary raw materials, construction materials, sludge, biowaste and (contaminated) soil. Waste Manag. 2003, doi: 10.1016/j.wasman.2003.09.002

14. Review of Scientific Literature on the Use of Stabilisation/Solidification for the Treatment of Contaminated Soil, Solid Waste and Sludges; Environment Agency: Bristol, UK, 2004.

15. Van der Sloot, H.A.; Kosson, D.S. Leaching Assessment Methodologies for Disposal and Use of Bauxite Residues; Hans van der Sloot Consultancy: Nashville, TN, USA, 2010.

16. Van der Sloot, H.A.; Meeussen, J.C.L.; van Zomeren, A.; Kosson, D.S. Developments in the characterisation of waste materials for environmental impact assessment purposes. J. Geochem. Explor. 2006, 88, 72-76.

17. Marguí, E.; Salvadó, V.; Queralt, I.; Hidalgo, M. Comparison of three-stage sequential extraction and toxicity characteristic leaching tests to evaluate metal mobility in mining wastes. Anal. Chim. Acta 2004, 524, 151-159.

18. Corus. Corus Corporate responsibility report 2007/08. In Sustainable Construction Solutions; Tata Steel Group: London, UK, 2008.

19. Steel industry by-products. Available online: http://www.worldsteel.org/publications/factsheets/content/01/text_files/file/document/Fact_By-products_2014.pdf (accessed on 12 April 2015).

20. Okoro, H.K.; Fatoki, O.S.; Adekola, F.A.; Ximba, B.J.; Snyman, R.G. A review of sequential extraction procedures for heavy metals speciation in soil and sediments. Open Access Sci. Rep. 2012, doi:10.4172/scientificreports. 181 .

21. Esakku, S.; Selvam, A.; Joseph, K.; Palanivelu, K. Assessment of heavy metal species in decomposed municipal solid waste. Chem. Speciat. Bioavailab. 2005, 17, 95-102.

22. Landreth, R.E.; Rebers, P.A. Municipal Solid Wastes: Problems and Solutions; Taylor \& Francis Inc. London, UK, 1996.

23. Templeton, D.M.; Ariese, F.; Cornelis, R.; Danielsson, L.-G.; Muntau, H.; van Leeuwen, H.P.; Lobinski, R. Guidelines for terms related to chemical speciation and fractionation of elements. Definitions, structural aspects, and methodological approaches (IUPAC Recommendations 2000). Pure Appl. Chem. 2000, 72, 1453-1470.

24. Environment Agency. SI 2004/1375; Environmental Protection: England and Wales, UK, 2004.

25. Environmental Protection. S.S.I. 2003/185; Environmental Protection: England and Wales, UK, 2003.

26. European Commission. Standard E12457; European Commission: Munich, Germany, 2002.

27. European Union. EU Council Decision, Annex 2003/33/EC; European Union: Maastricht, The Netherlands, 2003. 
28. Environmental Permitting Guidance: The Landfill Directive; Department for Environment, Food \& Rural Affairs: Bristol, United Kingdom, 2010.

29. British Standards Institue. BS EN 12457-3: Characterisation of waste. Leaching. In Compliance Test for Leaching of Granular Waste Materials and Sludges. Two Stage Batch Test at a Liquid to Solid Ratio of 2 1/kg and 8 1/kg for Materials with a High Solid Content and with a Particle Size below 4 mm (without or with Size Reduction); British Standards Institue: London, UK, 2002.

30. Saveyn, H.; Eder, P.; Garbarino, E.; Muchova, L.; Hjelmar, O.; van der Sloot, H.; Comans, R.; van Zomeren, A.; Hyks, J.; Oberender, A. Study on Methodological Aspects Regarding Limit Values for Pollutants in Aggregates in the Context of the Possible Development of End-of-Waste Criteria under the EU Waste Framework Directive; EUR-Scientific and Technical Research Reports; Institute for Prospective Technological Studies: Seville, Spain, 2014.

31. AWE International. Available online: http://www.aweimagazine.com/article.php?article_id=1081 (accessed on 14 September 2015).

32. Williams, P.T. Waste Treatment and Disposal, 2nd ed.; John Wiley \& Sons: Hoboken, NJ, USA, 2005.

33. Kumpiene, J.; Mench, M.; Bes, C.M.; Fitts, J.P. Assessment of aided phytostabilization of coppercontaminated soil by X-ray absorption spectroscopy and chemical extractions. Environ. Pollut. 2011, 159, 1-7.

34. Baeyens, W.; Monteny, F.; Leermakers, M.; Bouillon, S. Evalution of sequential extractions on dry and wet sediments. Anal. Bioanal. Chem. 2003, 376, 890-901.

35. Dahlin, C.L.; Williamson, C.A.; Collins, W.K.; Dahlin, D.C. Sequential extraction versus comprehensive characterization of heavy metal species in brownfield soils. Environ. Forensics 2002, 3, 191-201.

36. CMP. Electric Arc Furnace Dust. In 1993 Overview; Electric Power Research Institute, Center for Materials Production: Palo Alto, CA, USA, 1993.

37. Chen, J.; Yan, X.; Wang, X.; Zhang, J.; Huang, J.; Zhao, J. Heavy metal chemical extraction from industrial and municipal mixed sludge by ultrasound-assisted citric acid. J. Ind. Eng. Chem. 2015, $27,368-372$.

38. Salomons, W.; Forstner, U. Trace-metal analysis on polluted sediments: Evaluation of environmental impact. Environ. Technol. Lett. 1980, 1, 506-517.

39. Baruah, N.K.; Kotoky, P.; Bhattacharyya, K.G.; Borah, G.C. Metal speciation in Jhanji River sediments. Sci. Total Environ. 1996, 193, 1-12.

40. Li, X.; Thornton, I. Chemical partitioning of trace and major elements in soils contaminated by mining and smelting activities. Appl. Geochem. 2001, 16, 1693-1706.

41. Ure, A.M.; Quevauviller, P.; Muntau, H.; Griepink, B. Speciation of heavy metals in soils and sediments. An account of the improvement and harmonization of extraction techniques undertaken under the auspices of the BRC of the Commission of the European Communities. Int. J. Environ. Anal. Chem. 1993, 51, 135-151.

42. Foldi, C.; Andree, C.A.; Mansfeldt, T. Sequential extraction of inorganic mercury in dumped blast furnace sludge. Environ. Sci. Pollut. Res. Int. 2015, doi:10.1007/s11356-015-4781-3.

43. Yildirim, I.Z.; Prezzi, M. Chemical, mineralogical, and morphological properties of steel slag. Adv. Civil Eng. 2011, doi:10.1155/2011/463638. 
44. Fatoki, O.S.; Mathabatha, S. An assessment of heavy metal pollution in the East London and Port Elizabeth harbours. Impact Factor Descr. 2002, 27, doi: org/10.4314/wsa.v27i2.4997.

45. Shawabkeh, R.A. Hydrometallurgical extraction of zinc from Jordanian electric arc furnance dust. Hydrometallurgy 2010, 104, 61-65.

46. Environmental Protection Agency. Available and Emerging Technologies for Reducing Greenhouse Gas Emissions from the Iron and Steel Industry; Environmental Protection Agency: Washington, DC, USA, 2012.

47. Hasanbeigi, A.; Price, L.K.; McKane, A.T. The State-of-the-Art Clean Technologies (SOACT) for Steelmaking Handbook, 2nd ed.; Asia Pacific Partnership on Clean Development and Climate: Washington, DC, USA, 2010.

48. Ricketts, J.A. How a Blast Furnace Works in Making Steel; American Iron and Steel Institute: Washington, DC, USA, 2014.

49. American Iron and Steel Institue. 2014, Volume 2014. Availvle online: http://www.steel.org/making-steel/how-its-made/steelmaking-flowlines.aspx (accessed on 18 January 2015).

50. World Coal Association. Availvle online: http://www.worldcoal.org/coal/uses-of-coal/coal-steel/ (accessed on 5 May 2014).

51. Daněk, T. Physical and chemical properties of sludge from iron and steel industry stabilised with coal fly ash. Zesz. Naukowe ATH -Inzynieria Wlokiennicza Ochr. Srodowiska 2006, 24, 34-41.

52. Swindley, S.P.; Charles, J.; Shillaker, D.; Williams, K. Control of effluents in steel production: Wastewater discharges at British Steel Port Talbot. Ironmak. Steelmak. 1998, 25, 29-33.

53. Vereš, J.; Lovás, M.; Jakabský, Š.; Šepelák, V.; Hredzák, S. Characterization of blast furnace sludge and removal of zinc by microwave assisted extraction. Hydrometallurgy 2012, 129-130, 67-73.

54. Das, B.; Prakash, S.; Reddy, P.S.R.; Biswal, S.K.; Mohapatra, B.K.; Misra, V.N. Effective Utilization of Blast Furnace Flue Dust of Integrated Steel Plants. Eur. J. Miner. Process. Environ. Prot. 2002, 2, 61-68.

55. Emery, J.J. Slag Utilization in Pavement Construction. In Extending Aggregate Resources-ASTM Special Technical Publication; American Society for Testing and Materials: Washington, DC, USA, 1982.

56. Dakun, V.I.; Esezobor, D.E.; Rostovsky, V.I. Reclamation of dumped sludge in steel industry. J. Repub. Environ. Control. Ration. Util. Nat. Resour. 1993, 1719, 92-96.

57. Mansfeldt, T.; Dohrmann, R. Chemical and mineralogical characterization of blast-furnace sludge from an abandoned landfill. Environ. Sci. Technol. 2004, 38, 5977-5984.

58. Navarro, C.; Díaz, M.; Villa-García, M.A.A. Physico-chemical characterization of steel slag. study of its behavior under simulated environmental conditions. Environ. Sci. Technol. 2010, 44, 53835388.

59. Proctor, D.M.; Fehling, K.A.; Shay, E.C.; Wittenborn, J.L.; Green, J.J.; Avent, C.; Bigham, R.D.; Connolly, M.; Lee, B.; Shepker, T.O.; et al. Physical and Chemical Characteristics of Blast furnace, basic oxygen furnace, and electric arc furnace steel industry slags. Environ. Sci. Technol. 2000, 34, $1576-1582$. 
60. Das, B.; Prakash, S.; Reddy, P.S.R.; Misra, V.N. An overview of utilization of slag and sludge from steel industries. Resour. Conserv. Recycl. 2007, 50, 40-57.

61. Besta, P.; Janovská, K.; Samolejová, A.; Beránková, A.; Vozňáková, I.; Hendrych, M. The cycle and effect of zinc in the blast-furnace process. Metalurgija 2013, 52, 197-200.

62. Integrated Pollution Prevention and Control. Best Available Techniques (BAT) Reference Document for Iron and Steel Production; European Parliament, Institute for Prospective Technological Studies: Seville, Spain, 2010.

63. Vereš, J.; Kajabský, Š.; Šepelák, V. Chemical, physical, morphological and structural characterization of blast furnace sludge. J. Basic Princ. Diffus. Theory Exp. Appl. 2010, doi: 10.1179/1743285514Y.0000000069.

64. Tessier, A.; Campbell, P.G.C.; Bisson, M. Sequential Extraction Procedure for the Speciation of Particulate Trace Metals. Anal. Chem. 1979, 51, 844-850.

65. Coetzee, P. Determination and speciation of heavy metals in sediments of the Hartebeespoort Dam By sequential extraction. Water SA 1993, 19, 291-300.

66. Stephens, S.R.; Alloway, B.J.; Parker, A.; Carter, J.E.; Hodson, M.E. Changes in the leachability of metals from dredged canal sediments during drying and oxidation. Environ. Pollut. 2001, 114, 407-413.

67. Svete, P.; Milacic, R.; Pihlar, B. Partitioning of $\mathrm{Zn}, \mathrm{Pb}$ and $\mathrm{Cd}$ in river sediments from a lead and zinc mining area using the BCR three-step sequential extraction procedure. J. Environ. Monit. 2001, 3, 586-590.

68. Guevara-Riba, A.; Sahuquillo, A.; Rubio, R.; Rauret, G. Assessment of metal mobility in dredged harbour sediments from Barcelona, Spain. Sci. Total Environ. 2004, 321, 241-255.

69. Yuan, C.G.; Shi, J.B.; He, B.; Liu, J.F.; Liang, L.N.; Jiang, G.B. Speciation of heavy metals in marine sediments from the East China Sea by ICP-MS with sequential extraction. Environ. Int. 2004, 30, 769-783.

70. Mossop, K.F.; Davidson, C.M. Comparison of original and modified BCR sequential extraction procedures for the fractionation of copper, iron, lead, manganese and zinc in soils and sediments. Anal. Chim. Acta 2003, 478, 111-118.

71. Davidson, C.M.; Duncan, A.L.; Littlejohn, D.; Ure, A.M.; Garden, L.M. A critical evaluation of the three-stage BCR sequential extraction procedure to assess the potential mobility and toxicity of heavy metals in industrially-contaminated land. Anal. Chim. Acta 1998, 363, 45-55.

72. Fernandez, E.; Jimenez, R.; Lallena, A.M.; Aguilar, J. Evaluation of the BCR sequential extraction procedure applied for two unpolluted Spanish soils. Environ. Pollut. 2004, 131, 355-364.

73. Alvarez, E.A.; Mochon, M.C.; Sanchez, J.C.J.; Rodriguez, M.T. Heavy metal extractable forms in sludge from wastewater treatment plants. Chemosphere 2002, 47, 765-775.

74. Bruder-Hubscher, V.; Lagarde, F.; Leroy, M.J.F.; Coughanowr, C.; Enguehard, F. Application of a sequential extraction procedure to study the release of elements from municipal solid waste inceration bottom ash. Anal. Chim. Acta 2002, 451, 285-295.

75. Thornton, I.; Farago, M.E.; Thums, C.R.; Parrish, R.R.; McGill, R.A.; Breward, N.; Fortey, N.J.; Simpson, P.; Young, S.D.; Tye, A.M.; et al. Urban geochemistry: Research strategies to assist risk assessment and remediation of brownfield sites in urban areas. Environ. Geochem. Health 2008, $30,565-576$. 
76. Kirpichtchikova, T.A.; Manceau, A.; Spadini, L.; Panfili, F.; Marcus, M.A.; Jacquet, T. Speciation and solubility of heavy metals in contaminated soil using X-ray microfluorescence, EXAFS spectroscopy, chemical extraction, and thermodynamic modeling. Geochim. Cosmochim. Acta 2006, 70, 2163-2190.

77. Li, J. Risk Assessment of Heavy Metals in Surface Sediments from the Yanghe River, China. Int. J. Environ. Res. Public Health 2014, 11, 12441-12453.

78. Goldsmith, J.G. Modern Analytical Chemistry,.1st Edition (Harvey, David) J. Chem. Educ. 2000, 77, 705.

79. Sharmin, S.; Zakir, H.M.; Shikazono, N. Fractionation profile and mobility pattern of trace metals in sediments of Nomi River, Tokyo, Japan. J. Soil Sci. Environ. Manag. 2010, 1, 1-14.

80. Moore, F.; Nematollahi, M.J.; Keshavarzi, B. Heavy metals fractionation in surface sediments of Gowatr bay-Iran. Environ. Monit Assess. 2015, 187, 4117.

81. Hanay, Ö.; Hasar, H.; Kocer, N.N.; Aslan, S. Evaluation for Agricultural Usage with Speciation of Heavy Metals in a Municipal Sewage Sludge. Bull. Environ. Contam. Toxicol. 2008, 81, 42-46.

82. Abu-Obaid, A.A. The Influence of Surfactants on the adsorption of heavy metal ions using inorganic legands in selected contaminated soil samples in Palestine; Ph.D. Thesis. An-Najah National University: Nablus, Palestine, 2010.

83. Elder, J.F. Metal biogeochemistry in surface-water systems - A review of principles and concepts. Aavaible online: http://pubs.usgs.gov/circ/1988/1013/report.pdf (accessed on 11 september 2015).

84. David, J.A.; Leventhal, J.S. Bioavailabilty of Metals, Chapter 2: Preliminarycompilation of Descriptive Geoenvironmental Mineral Deposit Models; Department of the Interior U.S Geological Survey: Denver, CO, USA, 1995.

85. Fadiran, A.O.; Tiruneh, A.T.; Mtshali, J.S. Assessment of Mobility and Bioavailability of Heavy Metals in Sewage Sludge from Swaziland through Speciation Analysis. Am. J. Environ. Prot. 2014, 3, 198-208.

86. Wilson, C.A.; Cresser, M.S.; Davidson, D.A. Sequential element extraction of soils from abandoned farms: An investigation of the partitioning of anthropogenic element inputs from historic land use. J. Environ. Monit. 2006, 8, 439-444.

87. Jensen, P.E.; Ottosen, L.M.; Pedersen, A.J. Speciation of Pb in industrially polluted soils. Water Air Soil Pollut. 2006, 170, 359-382.

88. Boenke, A. The standards, measurements and testing programme (SMT), the European support to standardisation, measurements and testing projects. In Modern Developments and Applications in Microbeam Analysis; Love, G., Nicholson, W.A.P., Armigliato, A., Eds.; Springer: Brussels, Belgium, 1998.

89. Bacon, J.R.; Hewitt, I.J.; Cooper, P. Reproducibility of the BCR sequential extraction procedure in a long-term study of the association of heavy metals with soil components in an upland catchment in Scotland. Sci. Total Environ. 2005, 337, 191-205.

90. Sutherland, R.A.; Tack, F.M.G. Fractionation of $\mathrm{Cu}, \mathrm{Pb}$ and $\mathrm{Zn}$ in certified reference soils SRM 2710 and SRM 2711 using the optimized BCR sequential extraction procedure. Environ. Res. 2003, $8,37-50$. 
91. Maiz, I.; Arambarri, I.; Garcia, R.; Millán, E. Evaluation of heavy metal availability in polluted soils by two sequential extraction procedures using factor analysis. Environ. Pollut. 2000, 110, 39.

92. Rauret, G.; López-Sánchez, J.F.; Sahuquillo, A.; Barahona, E.; Lachica, M.; Ure, A.M.; Davidson, C.M.; Gomez, A.; Lück, D.; Bacon, J. Application of a modified BCR sequential extraction (three-step) procedure for the determination of extractable trace metal contents in a sewage sludge amended soil reference material (CRM 483), complemented by a three-year stability study of acetic acid and EDTA extractable metal content. J. Environ. Monit. 2000, 2, 228-233.

93. Nyamangara, J. Use of sequential extraction to evaluate zinc and copper in a soil amended with sewage sludge and inorganic metal salts. Agric. Ecosyst. Environ. 1998, 69, 135-141.

94. Usero, J.; Gamero, M.; Morillo, J.; Gracia, I. Comparative study of three sequential extraction procedures for metals in marine sediments. Environ. Int. 1998, 24, 487-496.

95. Cuong, D.T.; Obbard, J.P. Metal speciation in coastal marine sediments from Singapore using a modified BCR-sequential extraction procedure. Appl. Geochem. 2006, 21, 1335-1346.

96. Prudent, P.; Domeizel, M.; Massiani, C. Chemical sequential extraction as decision-making tool: Application to municipal solid waste and its individual constituents. Sci. Total Environ. 1996, 178, $55-61$.

97. Emmerson, R.H.; Birkett, J.W.; Scrimshaw, M.; Lester, J.N. Solid phase partitioning of metals in managed retreat soils: Field changes over the first year of tidal inundation. Sci. Total Environ. 2000, 254, 75-92.

98. Wepener, V.; Vermeulen, L. A note on the concentrations and bioavailability of selected metals in sediments of Richards Bay Harbour, South Africa. S. Afr. Water Res. Comm. 2005, 31, 589-596.

99. Flyhammar, P. Use of sequential extraction on anaerobically degraded municipal solid waste. Sci. Total Environ. 1998, 212, 203-215.

100. Zimmerman, A.J.; Weindorf, D.C. Heavy metal and Trace metal analysis in soil by sequential extraction: A review of procedures. Int. J. Anal. Chem. 2010, 2010, 7.

101. Clevenger, T.E. Use of sequential extraction to evaluate the heavy metals in mining wastes. Water Air Soil Pollut. 1990, 50, 241-254.

102. Buchholz, B.A.; Landsberger, S. Leaching dynamics studies of municipal solid waste incinerator ash. Air Waste Manag. Assoc. 1995, 45, 579-590.

103. Peralta, G.L.; Graydon, J.W.; Kirk, D. Physicochemical characteristics and leachability of scale and sludge from Bulalo geothermal system, Philippines. Geothermics 1996, 25, 17-35.

104. Salim, I.; Miller, C.J.; Howard, J.L. Sorption isotherm-sequential extraction analysis of heavy metal retention in landfill liners. Soil Sci. Soc. Am. J. 1996, 60, 107-114.

105. Spear, T.M.; Svee, W.; Vincent, J.H.; Stanisich, N. Chemical speciation of lead dust associated with primary lead smelting. Environ. Health Perspect. 1998, 106, 565-571.

106. Sammut, M.L.; Rose, J.; Masion, A.; Fiani, E.; Depoux, M.; Ziebel, A.; Hazemann, J.L.; Proux, O.; Borschneck, D.; Noack, Y. Determination of zinc speciation in basic oxygen furnace flying dust by chemical extracions and X-ray spectroscopy. Chemosphere 2008, 70, 1945-1951.

107. Fuentes, A.; Lloréns, M.; Sáez, J.; Isabel Aguilar, M.A.; Ortuño, J.F.; Meseguer, V.F. Comparative study of six different sludges by sequential speciation of heavy metals. Bioresour. Technol. 2008, 99, 517-525. 
108. Mäkelä, M.; Välimäki, I.; Pöykiö, R.; Nurmesniemi, H.; Dahl, O. Evaluation of trace element availability from secondary metallurgical slag generated in steelmaking by sequential chemical extraction. Environ. Sci. Technol. 2013, 10, 1193-1208.

109. Yao, J.; Kong, Q.; Zhu, H.; Long, Y.; Shen, D. Content and fractionation of Cu, Zn and Cd in size fractionated municipal solid waste incineration bottom ash. Ecotoxicol. Environ. Saf. 2013, 94, 131-137.

110. Mäkelä, M.; Heikinheimo, E.; Välimäki, I.; Dahl, O. Characterization of industrial secondary desulphurization slag by chemical fractionation with supportive X-ray diffraction and scanning electron microscopy. Int. J. Miner. Process. 2015, 134, 29-35.

111. Anju, M.; Banerjee, D.K. Comparison of two sequential extraction procedures for heavy metal partitioning in mine tailings. Chemosphere 2010, 78, 1393-1402.

112. Brumer, G.W.; Gerth, J.; Herms, U. Heavy Metal Species, Mobility and Availability in Soils; Bodenk, Z.P., Ed.: Wiley-VCH Verlag GmbH \& Co. KGaA: Weinheim, Germany, 1986.

113. Salomons, W. Environmental impact of metals derived from mining activities: Processes, predictions, prevention. J. Geochem. Explor. 1995, 52, 5-23.

114. Rauret, G. Extraction procedures for the determination of heavy metals in contaminated soil and sediment. Talanta 1998, 46, 449-455.

115. Camobreco, V.; Richards, B.K.; Steenhuis, T.S.; Peverly, J.H.; McBride, M.B. Movement of heavy metals through undisturbed and homogenized soil columns. Soil Sci. 1996, 161, 740-750.

116. Bohn, H.L.; Myer, R.A.; O’Connor, G.A. Soil Chemistry, 3rd ed.; John Wiley \& Sons: Hoboken, NJ, USA, 2001.

117. Matichenkov, V.V.; Bocharnikova, E.A. Studies in Plant. Science; Datnoff, L.E., Snyder, G.H., Korndörfer, G.H., Eds.; Elsevier: Amsterdam, The Netherlands, 2001; Volume 8, pp. 209-219.

118. Radosz, M.; Gawdzik, J. Impact assessment of microwave hygenization of sewage sludge on heavy metal mobility. Tech. Sanit. 2005, doi: 10.11648/j.ajep.20140304.14.

119. Hall, G.P.; Pelchat, P. Comparability of results obtained by the use of different extraction schemes for the determination of element froms in soils. Water Air Soil Pollut. 1999, 112, 41-53.

120. Luoma, S.N. Can we determine the biological availability of sediment-bound trace elements? Hydrobiologia 1989, 176-177, 379-396.

121. Leimalm, U.; Lundgren, M.; Ökvist, L.S.; Björkman, B. Off-gas dust in an experimental blast furnace, Part 1: Characterization of flue dust, sludge and shaft fines. ISIJ Int. 2010, 50, 1560-1569.

122. Kelebek, S.; Yörük, S.; Davis, B. Characterization of basic oxygen furnace dust and zinc removal by acid leaching. Miner. Eng. 2004, 17, 285-291.

123. Sarkar, A.; Rano, R.; Mishra, K.K.; Sinha, I.N. Particle size distribution profile of some Indian fly ash-A comparative study to assess their possible uses. Fuel Process. Technol. 2005, 86, $1221-$ 1238 .

124. Zhan, G.; Guo, Z. Study on basic properties of sintering dust from iron and steel plant and potassium recovery. J. Environ. Sci. 2013, 25, 1226-1234.

125. Cantarino, M.V.; de Carvalho Filho, C.; Borges Mansur, M. Selective removal of zinc from basic oxygen furnace sludges. Hydrometallurgy 2012, 111-112, 124-128.

126. Mihaiescu, D.C., Predeanu, G.; Panaitescu, C. Characterisation of some blast furnace waste dusts, U.P.B. Sci. Bull. 2014, 76, 227-234. 
127. Ismail, K.N.; Hussin, K.; Idris, M.S. Physical, cheimcal and mineralogical properties of fly ash. J. Nucl. Relat. Technol. 2007, 4, 47-51.

128. Rauret, G.; López-Sánchez, J.F. New sediment and soil CRMs for extractable trace metal content. Int. J. Environ. Anal. Chem. 2001, 79, 81-95.

129. Snoeyink, V.L.; Jenkins, D. Water Chemistry; John Wiley and Sons: New York, NY, USA, 1980.

130. Marin, B.; Valladon, M.; Polve, M.; Monaco, A. Reproducibility testing of a sequential extraction scheme for the determination of trace metal speciation in a marine reference sediment by inductively coupled plasma-mass spectrometry. Anal. Chim. Acta 1997, 342, 91-112.

131. Klock, P.R.; Czamanske, G.K.; Foose, M.; Pesek, J. Selective chemical dissolution of sulfides: An evaluation of six methods applicable to assaying sulfide-bound nickel. Chem. Geol. 1986, 54, 157-162.

132. Filgueiras, A.V.; Lavilla, I.; Bendicho, C. Chemical sequential extraction for metal partitioning in environmental solid samples. J. Environ. Monit. 2002, 4, 823-857.

133. Fan, W.; Wang, W.X.; Chen, J. Geochemistry of Cd, Cr, and Zn in highly contaminated sediments and its influences on assimilation by marine bivalves. Environ. Sci. Technol. 2002, 36, 5164-5171.

134. Gleyzes, C.; Tellier, S.M.; Astruc, M. Fractionation studies of trace elements in Contaminated soils and Sediments: A review of sequential extraction procedure. Trend Anal. Chem. 2002, 21, 451467.

135. Dollar, N.L.; South, G.M.; Filipelli, G.M.; Mastalerz, M. Chemical fractionation of metals in wetland sediments: Indiana dunes national lakeshore. Environ. Sci. Technol. 2001, 35, 3608-3615.

136. Borovec, Z.; Tolar, V.; Mraz, L. Distribution of some metals in sediments of the central part of the Labe (Eibe) River: Czeech Republic. Ambio 1993, 22, 200-205.

137. Kullgren, A.; Campanella, L.; D’Orazio, D.; Petronio, B.M.; Pietrantonio, E. Proposal for a metal speciation study in sediments. Anal. Chim. Acta 1995, 309, 387-393.

138. Borovec, Z. Evaluation of the concentrations of trace elements in stream sediments by factor and cluster analysis and the sequential extraction procedure. Sci. Total Environ. 1996, 177, 237-250.

139. Gomez-Ariza, J.L.; Giraldez, I.; Sanchez-Rodas, D.; Rodas, E. Morales. Metal sequential Extraction Procedure optimized for heavy metal polluted and iron oxide rich sediments. Anal. Chim. Acta 2000, 414, 151-164.

140. Chang, A.C.; Page, A.L.; Warneke, J.E.; Grgurevic, E. Sequential extraction of soil heavy metals following a sludge applications. J. Environ. Q. 1984, 13, doi:10.2134/jeq1984.0047242500130 0010006x.

141. Salomons, W. Adoption of common schemes for single and sequential extractions of trace metal in soils and sediments. Int. J. Environ. Anal. Chem. 1993, 51, 3-4.

142. Fiedler, H.D.; López-Sánchez, J.F.; Rubio, R.; Rauret, G.; Quevauviller, Ph.; Ure, A.M.; Muntau, H. Study of the stability of extractable trace metal contents in a river sediment using sequential extraction. Analyst 1994, 119, 1109-1114.

143. Ho, M.D.; Evans, G.J. Operational Speciation of Cadmium, Copper, Lead and Zinc in the NIST Standard Reference Materials 2710 and 2711 (Montana Soil) by the BCR Sequential Extraction Procedure and Flame Atomic Absorption Spectrometry. Anal. Commun. 1997, 34, 363-364. 
144. López-Sánchez, J.F.; Sahuquillo, A.; Fiedler, H.D.; Rubio, R.; Rauret, G.; Muntau, H.; Quevauviller, P. CRM 601, A stable material for its extractable content of heavy metals. Analyst 1998, 123, 1675-1677.

145. Smeda, A.; Zyrnicki, W. Application of sequential extraction and the ICP-AES method for study of the partitioning of metals in fly ashes. Microchem. J. 2002, 72, 9-16.

146. Ramos, L.; Hernandez, L.M.; Gonzalez, M.J. sequential fractionation of copper, lead, cadmium and zinc in soils from or near Doñana National Park. J. Environ. Qual. 1994, 23, 50-57.

147. Qiang, T.; Xiao-quan, S.; Zhe-ming, N. Evaluation of a sequential extraction procedure for the fractionation of amorphous iron and manganese oxides and organic matter in soils. Sci. Total Environ. 1994, 151, 159-165.

148. Benitez, L.N.; Dubois, J.P. Evaluation of the selectivity of sequential extraction procedures applied to the speciation of cadmium in soils. Int. J. Environ. Anal. Chem. 1999, 74, 289-303.

149. Atkins, P.; Paulo, J.D. Physical Chemistry, 10th ed.; OUP Oxford: Oxford, UK, 2014.

150. Martin, J.M.; Nirel, P.; Thomas, A.J. Sequential extraction techniques: Promises and problems. Mar. Chem. 1987, 22, 311-341.

151. Hlavay, J.; Prohaska, T.; Weisz, M.; Wenzel, W.W.; Stingeder, G.J. Determination of trace elements bound to soils and sediment fractions. Pure Appl. Chem. 2004, 76, 415-442.

152. Van der Sloot, H.; Dijkstra, J. Development of Horizontally Standardized Leaching Tests for Construction Materials: A Material Based or Release Based Approach? Identical Leaching Mechanisms for Different Materials; Energy Research Center of the Netherlands: Petten, Netherlands, 2004.

153. Van Herck, P.; van der Bruggen, B.; Vogels, G.; Vandecasteele, C. Application of computer modelling to predict the leaching behaviour of heavy metals from MSWI fly ash and comparison with a sequential extraction method. Waste Manag. 2000, 20, 203-210.

154. Van Herck, P.; Vandecasteele, C. Evaluation of the use of a sequential extraction procedure for the characterization and treatment of metal containing solid waste. Waste Manag. 2001, 21, 685-694.

155. Malviya, R.; Chaudhary, R. Leaching behavior and immobilization of heavy metals in solidified/stabilized products. J. Hazard. Mater. 2006, 137, 207-217.

156. Fällman, A.M. Leaching of chromium and barium from steel slag in laboratory and field tests-A solubility controlled process? Waste Manag. 2000, 20, 149-154.

157. Qiu, H.; Gu, H.-H.; He, E.-K.; Wang, S.-Z.; Qiu, R.-L. Attenuation of metal bioavailability in acidic multi-metal contaminated soil treated with fly ash and steel slag. Pedosphere 2012, 22, 544-553.

158. Cappuyns, V.; Swennen, R.; Niclaes, M. Application of the BCR sequential extraction scheme to dredged pond sediments contaminated by $\mathrm{Pb}-\mathrm{Zn}$ mining: A combined geochemical and mineralogical approach. J. Geochem. Explor. 2007, 93, 78-90.

159. Nemati, K.; Bakar, N.K.A.; Abas, M.R.; Sobhanzadeh, E. Speciation of heavy metals by modified BCR sequential extraction procedure in different depths of sediments from Sungai Buloh, Selangor, Malaysia. J. Hazard. Mater. 2011, 192, 402-410.

160. Bódog, I.; Polyák, K.; Csikós-Hartyányi, Z.; Hlavay, J. Sequential extraction procedure for the speciation of elements in Fly Ash Samples. Microchem. J. 1996, 54, 320-330. 
161. Kirk, D.W.; Chan, C.C.Y.; Marsh, H. Chromium behavior during thermal treatment of MSW fly ash. J. Hazard. Mater. 2002, 90, 39-49.

162. Wan, X.; Wang, W.; Ye, T.; Guo, Y.; Gao, X. A study on the chemical and mineralogical characterization of MSWI fly ash using a sequential extraction procedure. J. Hazard. Mater. 2006, 134, 197-201.

163. Sukandar, S.; Yasuda, K.; Tanaka, M.; Aoyama, I. Metals leachability from medical waste incinerator fly ash: A case study on particle size comparison. Environ. Pollut. 2006, 144, 726-735.

164. Leinz, R.W.; Sutley, S.J.; Desborough, G.A.; Briggs, P.H. ICARD 2000. In Proceedings of the Fifth International Conference on Acid Rock Drainage , Denver, CO, USA, 24-27 January 2000; Society for Mining, Metallurgy, and Exploration: Englewood, CO, USA, 2000; Volume II.

165. Laforest, G.; Duchesne, J. Characterization and leachability of electric arc furnace dust made from remelting of stainless steel. J. Hazard. Mater. 2006, 135, 156-164.

(C) 2015 by the authors; licensee MDPI, Basel, Switzerland. This article is an open access article distributed under the terms and conditions of the Creative Commons Attribution license (http://creativecommons.org/licenses/by/4.0/). 